\title{
APROXIMACIÓN A LA PINTURA ARGELINA CONTEMPORÁNEA
}

\author{
Dianelys Blanco González \\ Universidad de Alicante
}

\begin{abstract}
Resumen
Se realiza en el presente trabajo una aproximación general a la historia de la pintura moderna y contemporánea en Argelia, a través de sus principales artistas y corrientes estéticas. Se estudia en un primer momento la influencia de la vida argelina para el desarrollo del gusto orientalista de la pintura occidental, para pasar a describir los primeros autores argelinos y la búsqueda de una expresión vernácula, entre la figuración y la abstracción. Un pequeño apéndice iconográfico se incluye al final de trabajo con el fin de visibilizar este patrimonio excepcional de la pintura argelina.
\end{abstract}

Palabras clave: Arte, pintura, Argelia, orientalismo, figuración, abstracción, modernidad.

\begin{abstract}
A general approach to the history of modern and contemporary painting in Algeria is undertook in this paper through its main artists and aesthetic trends. The influence of Algerian life for the development of the Orientalist taste of Western painting is studied at first, to go on to describe the first Algerian authors and the search for a vernacular expression, between figuration and abstraction. A small iconographic appendix is included at the end of the work in order to make visible this exceptional heritage of Algerian painting.
\end{abstract}

Keywords: Art, painting, Algeria, orientalism, figuration, abstraction, modernity.

\section{INTRODUCCIÓN}

Muchas comunidades culturales se han instalado a lo largo de la historia en el Magreb central. Hoy en día la moderna República de Argelia posee una gran variedad cultural y étnica. La pintura argelina contemporánea se va a desarrollando de forma paralela a la construcción de la nación, al movimiento nacionalista. Las artes plásticas nacen de una doble herencia: la herencia colonial que tuvo un impacto innegable sobre el desarrollo de las técnicas pictóricas, y la herencia tradicional fomentada desde la voluntad de los artistas deseosos de desarrollar un arte argelino ligado a las tradiciones culturales y técnicas de la propia tierra. Esta idea de doble 
herencia ha marcado de algún modo el desarrollo de la expresión plástica hasta nuestros días ${ }^{1}$.

\section{Argelia Vista POR LOS PINTORES OCCIDENTALES MODERNOS}

Durante la edad moderna muchos fueron los autores europeos, sobre todo franceses, que quedaron influidos por los paisajes y la cultura argelina. Argelia será objeto pictórico al tiempo que idea estética, puerta hacia un estilo y un espíritu orientalistas de la pintura romántica.

En I834 Eugène Delacroix (I798-1863) estableció nuevos parámetros en la pintura francesa al pintar Mujeres de Argel, un ejemplo de sensualidad orientalista. Se trata de un óleo sobre lienzo de $180 \mathrm{~cm}$. de alto y $2219 \mathrm{~cm}$. de ancho, actualmente en el Museo del Louvre. Delacroix viajó a Argel en I832, dentro de una misión diplomática francesa. Durante este viaje no dejó de dibujar y pintar acuarelas de todo aquel mundo que le resultaba exótico. Una de las experiencias más inusuales de Delacroix durante este viaje fue poder entrar en un harén. Hizo un boceto a la acuarela con sus impresiones, apuntando a lápiz los colores. Dos años después recompuso la escena en su taller de París. Parte del rostro de la mujer de la izquierda queda inmerso en la sombra. El pintor usó esta técnica en muchas figuras para lograr un aire de misterio y aislamiento. A su lado están sentadas otras dos mujeres mientras que otra figura femenina, una criada negra, está en pie; su presencia, de espaldas y girando, parece hacer entrar al espectador en el cuadro. Destaca la forma en que la luz está representada. Es una luz lógica, proveniente de una ventana, sin un efecto que exceda o idealice la realidad. Delacroix quedó entusiasmado por la luz natural del norte de África, y pretendió plasmarla en sus obras.

En 1836 los pintores franceses, dentro del estilo clásico, académico e historicista también pintaban las batallas sobre el asedio y las conquistas en África, en especial de Argel. De este modo encontramos El asedio de Constantina, un intento francés del mariscal Bertrand Clauzel por tomar

1 Para una relación general de la historia de la pintura argelina moderna y contemporánea, remitimos a las obras generales sobre el tema: Marion Vidal-Bué, Alger et ses peintres (1830-1960), París, Paris-Méditerranée, 2000; idem, L'Algérie des peintres (1830-1960), Argel, Edif 2000 /París, Paris-Méditerranée, 2002. Sigue siendo escasa la bibliografía en lengua española sobre el arte en el Magreb. Véase al respecto Julia Barroso Villar, Arte contemporáneo en el Norte de África: Egipto, Túnez, Argelia y Marruecos, Oviedo, [s.n.], 2014. 
la ciudad en manos de Ahmed Bey, el último dignatario de la Regencia de Argel. En esta obra se detalla la retirada de los franceses en la toma de Constantina. En I837 el pintor francés Emile Jean Horace Vernet (I7891863) pintaba la toma de la misma Constantina. Vernet destacó por ser un pintor bélico, clasicista y academicista.

Otra de las obras más conocidas de la pintura impresionista francesa sobre Argelia, la encontramos en Pierre Auguste Renoir (I84I-I9I9), cuando en 1870 realiza un retrato con pincelada suelta de su famosa Odalisca o la argelina. En esta obra se representaban los temas del sueño, y de la moda de Oriente, se trata de una pintura al óleo sobre lienzo. Delacroix puso de moda la pintura orientalista y Renoir, que admiraba a Delacroix, pintó esta Odalisca para la que posó Lise Tréhot, la misma modelo de la Diana cazadora y Lise con sombrilla. La obra fue presentada al Salón de París de 1870 y creada especialmente para obtener el triunfo. El crítico Houssaye consideró que se trataba de una "Argelina que firmaría el mismo Delacroix". El joven artista vuelca su interés en la temática oriental atraído por los colores, los ambientes y los trajes de esta región, utilizando el ideal de la "mujer de Argel" como motivo de nueva concepción cromática. Las pinceladas son rápidas, sin atender al detalle, interesándose más por el efecto del conjunto que por la calidad táctil de las telas. Sin embargo, el dibujo es preciso. Con una pincelada más suelta pintaría su Jeune Fille algérienne en I88I.

Mención aparte merece Étienne Dinet (I86I-I929), pintor francés academicista que se estableció en Argelia y se convirtió al Islam con el nombre de Naṣr al-Dīn Dīnāt / نصر الديـن دينـات Su obra representa una influencia directa en los precursores del arte moderno argelino, sobre todo en su segunda etapa de mayor reflexión religiosa, pues en muchos casos su pintura muestra escenas anecdóticas de género. Así se ve en $L a$ mensajera de Satanás (1908), obra que se encuentra en el Museo de Bellas Artes de Buenos Aires.

Henri Matisse (1869-1954) dentro de la corriente fauvista y el empleo del color puro, pinta su famoso retrato de la mujer argelina en 1909. El año I9I4, el pintor August Macke (I887-I9I4) realiza una acuarela titulada Mercado en Argel. Pintor alemán expresionista, se trata de una pintura 
tranquila, amable, alejada de rasgo alguno de agresividad y tensiones propiciada por su espíritu optimista, sin prescindir de la figuración.

Durante la última etapa de su vida, Pablo Picasso (I88I-I973) empezó a pintar una serie de interpretaciones de sus obras preferidas, entre ellas Mujeres de Argel, pintada en I955 y basada en la sensual obra de 1834 de Eugène Delacroix. Picasso siempre sintió predilección por esta obra llena de sugestión. Como gran amante y pintor erótico, esta obra le provocaba las más delirantes fantasías orientales. Así, el genio malagueño hizo un tributo al talento romántico del pintor francés Delacroix. Picasso comenzó a pintar una serie de variaciones libres sobre el cuadro en diciembre de I954, seis semanas después de conocer la muerte de su amigo y rival Matisse. En 2015 este cuadro del pintor español se convirtió en el más caro de la historia al venderse en la casa Christie's de Nueva York por I6o millones de dólares.

Finalmente, la pintora alemana Bettina Heinen-Ayech (1937-) hizo de Argelia su país de adopción, mostrando sus paisajes con un extraordinario colorido. A comienzos de los noventa el Museo de Baden de Solingen y el Museo de Bellas Artes de Argel le dedicaron dos retrospectivas. El Museo de Solingen en el año 2000 presentó una exposición sobre los treinta y siete años de trabajo de Bettina en Argelia. A finales de 2004, el Museo de Bellas Artes de Argel le honró nuevamente, a través de una segunda retrospectiva que reunió unos sesenta paisajes, retratos y autorretratos.

\section{LOS PRECURSORES: DEL ACADEMICISMO A LA PINTURA MINIATURISTA}

Azouaou Mammeri (I886-I954), Abdelhalim Hemche (I906-I978), Mohammed Zmirli (I909-I984), Ahmed Benslimane (I916-I951) y Miloud Boukerche (I920-I979) son los primeros en introducir en la cultura argelina la práctica de la pintura de caballete. Están influenciados por los modelos estéticos del academicismo francés, aunque con la visión de la realidad argelina, siguen los modelos orientalistas franceses. Se trata de pintores figurativos y realistas ${ }^{2}$.

2 Para biografías y datos específicos de los autores mencionamos, remitimos a los diversos diccionarios existentes de artistas argelinos: Mansour Abrous, Dictionnaire des Artistes Algériens (1917-2006), París, L'Harmattan, 2006; Djamila Flici-Guendil, Diwan al-fen: dictionnaire des peintres, sculpteurs et designers Algériens, Argel, AnEP-EnAG, 2008; y Élisabeth Cazenave, Les artistes de 
Al mismo tiempo, otros artistas están trabajando para revivir la tradición de la iluminación y la religión islámica e introducir en Argelia el género oriental de la miniatura. En este sentido destacan Mohamed Racim (I896-1974), Mohamed Temmam (1915-1988) y Mostéfa Ben Debbagh (1906-2006) donde en sus pinturas de miniaturas denotan la nostalgia de los esplendores de los patios, palacios, princesas, cuencas y gacelas del pasado islámico. En estas dos formas, se desarrolla la figuración en Argelia, en el terreno de varios milenios de expresiones populares simbólicas abstractas, bereberes y árabes, integradas en la vida cotidiana a través de la arquitectura y el arte.

Mohammed Ben Ali Racim (I896-I975) pintor, miniaturista y especialista en caligrafía árabe, trabajó la vida de Mahoma de forma ilustrada, y realizó ilustraciones de Barbarroja y Boustan de Saadi. Dentro de la Escuela miniaturista de Argel, fue un propagandista de la cultura popular, pintor detallista y meticuloso.

Mohamed Temmam está considerado un genio de la pintura miniaturista. Trabajó también en la decoración de cerámica.

La pintura miniaturista seguirá a lo largo de todo este tiempo junto a nuevas corrientes artísticas y con pintores que abrazaron nuevas tendencias del momento como el expresionismo, el cubismo o el fauvismo, como fue el caso de Bachir Yellès, nacido en I92I.

\section{La Generación de i93o}

La Generación de 1930 estaría compuesta por una decena de autores, cuya principal consigna es impugnar la visión figurativa y narrativa, teóricamente ajena a la sensibilidad del Magreb. Varias tendencias se afirman, arte ingenuo y expresionismo, no figuración y pintura del signo.

Algunos de los miembros de esta generación, como Issiakhem y Mesli, asistieron a las escuelas de Bellas Artes de Argel y París, o, para Guermaz y Benanteur, la de Orán. Otros, autodidactas, se han dedicado solemnemente a su arte, Baya, Khadda, tipógrafo, Aksouh, herrero, Zerarti, albañil. En una ruta comparable a la de los primeros grandes escritores argelinos de lengua francesa, algunos de estos pintores, atraídos por la 
efervescencia artística que se ha manifestado desde principios de siglo, pasaron mucho tiempo en París, cuna de la pintura, caso de Issiakhem, Khadda y Mesli, mientras que otros se instalarán de forma permanente, Benanteur, Guermaz o Aksouh. Tres tendencias van a aparecer desde un principio: I) arte naif, surrealista; 2) arte expresionista; y 3) arte abstracto sin ningún tipo de figuración.

\section{Arte naï y surrealista}

Descrito como 'ingenuo', aparece con Hacène Benaboura (I898-I96I) y está esencialmente encarnado por Baya Mahieddine (I93I-I998), llamada en realidad Fatma Haddad cuyo «arte brut» se convertirá en uno de los símbolos de la creación argelina. Baya, doblemente huérfana a los 5 años y en acogida desde los I2, destacó por sus gouachés. Con i6 años ya realizó su primera exposición, aunque después de casarse estuvo una década inactiva. En 1963, recupera sus papeles y sus gouachés. Destacan las falsas simetrías de sus composiciones, un color brillante y sus líneas puras circulares, presente en obras como Las altas señoras, o figuras enigmáticas de La madre, con rostros transparentes, blanca piel, ojos brillantes y pelo azabache. Los ramos, las jarras y las frutas, más tarde los instrumentos musicales y toda la fauna paralela de peces, aves y mariposas que los acompañan, desatados de cualquier volumen, se destacan bajo una luz extendida en un espacio que rechaza cualquier perspectiva ilusionista.

Las mujeres, los pájaros, los peces y las plantas aparecen con frecuencia en el espacio estrecho y sin márgenes de Baya, que llegó a conocer a Picasso en Francia y André Breton la incluyó en la segunda exposición surrealista en París en I947. Las figuras humanas, los ornamentos y las plantas se llenan de colores vivos, y los contornos gruesos y los motivos enérgicos dominan muchas de las composiciones. Durante la guerra de Argelia con Francia, se casó y dejó de pintar, pero durante la postguerra continuó su labor con dos obras importantes: Sin título y Las dos músicas. La artista llena el lienzo de borde a borde. Apenas queda espacio vacío en unas obras que irradian una energía procedente de sus pinceladas y del uso intensivo de azules, rojos y amarillos. Estos cuadros muestran los lugares en los que se reúnen las mujeres, ya sea para tocar música o para conversar y relajarse, con miradas ciertamente profundas. 


\section{Expresionismo}

Destaca un expresionismo más figurativo en las visiones coloridas de Ahmed Kara-Ahmed (1923) y Mohamed Bouzid (1929-20I4) o, más dramáticamente, Ismail Samsom (I934-I988). Una segunda tendencia expresionista está dominada por la personalidad de M'hamed Issiakhem (1928-1985). Con I5 años manipula una granada recogida en un campamento militar estadounidense y en la explosión mueren dos de sus hermanas y un sobrino; a él le amputaron el antebrazo. El pintor refleja el sufrimiento argelino durante los años de guerra, y el sufrimiento de los desarraigados, la exigencia de dignidad. Nunca dejará de reactivar el clima angustiado de su pintura que exorciza los dolores de un drama personal y la violencia del mundo. Se trata de una 'Historia colectiva'. En una furiosa solidaridad con hombre y mujeres en todas las latitudes amuralladas en el silencio de la miseria o la opresión, el gesto de Issiakhem resalta todos los rostros de la miseria de la pasta espesa. Las celebraciones del universo materno, de una serenidad de la que se ha privado al pintor, constituirán tantos conjuros de lo trágico de la condición humana.

Salah Hioun (1936-2017) fue un destacado grabador. Estuvo en Francia de 1953 a 1963. Del mismo modo que Issiakhem, su obra expresionista está marcada por la guerra de independencia contra Francia, el sufrimiento del pueblo argelino y la represión ejercida. Su obra también refleja el sufrimiento de las mujeres, en su visión particular de retratos.

Abdelkhader Houamel (1936-2018) es uno de los primeros pintores y luchadores del Ejército de Liberación de Argelia, y uno de los primeros pintores del Frente de Liberación Nacional de Argelia que expuso durante la Guerra de Argelia en I96o en Túnez en su etapa expresionista. Houamel está considerado uno de los fundadores de la pintura moderna argelina. En 1960 se presentó su primera exposición individual, en el Salon des Arts de Túnez. A continuación comenzó a estudiar en la Academia de Bellas Artes de Roma. En 1963, recibió una medalla de oro en arte árabe, y desde 1967 ha sido objeto de varias exposiciones internacionales. Vivió en Italia desde 1960. Tiene una etapa expresionista y otra marcadamente abstracta, evolucionando hacia el neoexpresionismo.

Ahmed Kara, nacido en 1923 en Argel, es uno de los promotores de las artes plásticas, pintor y escultor con una obra prolífica en estilos desde sus 
inicios expresionistas hasta su realismo actual, pasando por la abstracción. También estudio grabado y ha expuesto sus obras en París, Estocolmo, y Helsinki, entre otros lugares. Fundador del Museo Nacional de Artes y Tradiciones Populares de Argel, fue su comisario durante muchos años.

\section{Abstracción y simbología}

Fue en los años sesenta, como consecuencia de la independencia de Argelia, un buen número de artistas jóvenes se desplazaron a París, tales Benanteur, Issiakhem, Guermaz, Khadda, Aksouh. Introdujeron nuevos conceptos como la abstracción, y se interesaron por la utilización del signo como acto de salvaguardia del lugar con su cultura de origen. Gracias a estos artistas fue restituyéndose el lugar con la memoria a través de la caligrafía o la simbología bereber. Y se huyó de la representación figurativa anterior.

Abdelkader Guermaz (I9I9-I996) es el mayor de su generación. En la década de 1940 expone sus pinturas libremente figurativas en las galerías de Orán. A partir de i961 y su instalación en París, sus pinturas, desprendidas de cualquier figuración, se enredan con enredos de vivos colores ascendentes. Luego pasa a sus lienzos un gran viento de luz que atrapa el empaste de la materia. Alrededor de 1975, un nuevo paisaje emerge de la sucesión de planos de colores superpuestos, altos acantilados o cursos solares de crestas o dunas. El misterio del espacio se fusiona con tensión. Se trata de una pintura de meditación que se dirige tanto a la mente como a los ojos.

Mohammed Khadda (I930-I99I) huye de la pintura figurativa. Para Khada la abstracción es el resultado de la desculturización occidental, y defendió la abstracción y denunció el "realismo oportunista”. En un enfoque donde la creación plástica y la reapropiación cultural se juntan, sus pinturas, acuarelas y grabados, basados en la expresiva plasticidad de la escritura árabe, le llevan a conocer los gráficos de paisajes y cosas, árboles o piedras, el mundo natural.

Abdallah Benanteur (I93I-20I7) comienza en la década de los cincuenta con unas pinturas de oscuras tierras donde apenas llega la luz. Posteriormente tiende hacia lo irreal, cuando las siluetas de sus Visitas de visita se encuentran en reuniones inciertas. Su pintura conduce a gargan- 
tas y desfiles, pases y claros de un Mediterráneo cuya memoria ilumina los colores. Pequeñas multitudes anónimas invaden por un momento los espacios, que se desvanecerán como espejismos. Produjo simultáneamente desde 196r más de mil libros únicos enriquecidos con acuarelas y dibujos.

\section{El GRUPO «AOUCHEM» Y LA ABSTRACCIÓN}

En la década de los años setenta la pintura argelina multiplica sus caminos y ve la emergencia de nuevas caras, como Akmoum, Zoubir-He1lal, Mesli, Chegrane... que siguen el mismo camino de los mayores utilizando también símbolos. Choukri Mesli y Denis Martínez también participaron en las primeras exposiciones celebradas en Argel y París después de la independencia. Ambos profesores de la Escuela de Bellas Artes de Argel, son animadores del grupo «Aouchem» (tatuaje) de I967 a I97I, que reúne a una docena de artistas, poetas y pintores, entre ellos Hamid Abdoun (I929-I998), Rezki Zérarti (1938) y Mustapha Akmoun (1946).

Se oponen a las imágenes — que consideran demagógicas- que se presentan en la galería oficial de la Unión Nacional de Artes Plásticas, fundada y presidida en 1963 por Bachir Yellès, continuador de la figuración miniaturista, pero cuyos pintores más activos están excluidos desde el principio. Según su manifiesto: "Aouchem nació hace milenios, en las paredes de una cueva prehistórica Tassili. Ha continuado su existencia hasta hoy, a veces en secreto, a veces abiertamente, de acuerdo con las fuctuaciones de la Historia [...] Pretendemos mostrar que, siempre mágico, el signo es más fuerte que las bombas".

Denis Martínez (194-) recurre aún más a las artes populares, los signos de tifinagh y los restos de antiguas caligrafías, también en los recuerdos de la cultura andalusí. Su influencia ha sido duradera en varias generaciones de artistas. En sus lienzos, pesadamente estructurados, se multiplican flechas gráficas que sugieren, en medio de un enjambre de puntos y líneas, estrellas y abejas, serpientes y lagartos, los movimientos y relaciones del personaje ubicuo, preocupado y cuestionando. 


\section{Tendencias actuales}

1. Neofauvismo y neoexpresionismo

Los años ochenta y noventa ven cómo nace una nueva forma de pintura que echa mano del neofauvismo continuado por Houammel y Cherfaqui hasta la actualidad. Y también del neoexpresionismo, esta experiencia es el reflejo de la inquietud y la angustia que viven los argelinos como consecuencia del terrorismo que conoció el país durante este período. Destacan los artistas Mokrani, S. Djeffal, A. A. Mameri, Belhachmi, Ait Harra, y Sergoua.

\section{Pintura figurativa}

A principios de la década de I990, después de la Guerra del Golfo y el frenazo de la emoción y la especulación en el mundo del mercado del arte de la época, muchos coleccionistas y comerciantes recurren a la pintura figurativa, otros artistas adoptaron un estilo introspectivo, meditativo donde resaltan formas más figurativas. Pertenecen a este reciente movimiento artistas como Bourdine, Louail, Oulhaci, Ali Khodja. Sus obras se caracterizan por un estilo donde sobresale una visión subjetiva y no realista.

\section{Abstracción, signo, diversos materiales y carteles}

Dentro de la abstracción, los materiales y los carteles se diversifican, los gráficos y los signos caligráficos presentes durante todo el siglo bajo diversos estilos. Majhoub Ben Bella (1946) y Rachid Koraichi (1947) se desvían vertiginosamente de la caligrafía oficial, utilizando aerosoles en sus pinturas. Ali Silem (I947) tejiendo la carta como flecos de lana con materiales dorados o calcinados de sus desiertos parece desplegar el espacio interno. Malek Salah (I949) y Saci Mohand (I949) forman parte de un interrogatorio del espacio que ignora esta dimensión de identidad, mientras que Hamida Chellali (I948), Samta Benyahia (1949) y Akila Mouhoubi (I953) conjugan en los remolinos de color o la acumulación simbólica, la pintura femenina. 
El trabajo de Hamid Tibouchi (195I) - reconocido por primera vez como uno de los principales representantes de la joven poesía argelina francófona- es característico de esta búsqueda del signo, que renueva y empuja hacia la intimidad de los materiales. Los tintes naturales, pigmentos, tintas y tintes, arena o carbón vegetal, que utiliza en los soportes más humildes, papeles, cartones o varios lienzos, cristalizan los mensajes ocultos. En la superficie de sus texturas aparecen, como las páginas de viejos pergaminos, de 'arqueografias' sin edad o de particiones internas donde se enredan y enredan una proliferación de 'grafemas salvajes'.

Renovando el espíritu de Aouchem, Zoubir Hellal (1952), uno de los animadores, forma con Karim Sergoua (1960) el reciente grupo «Essebaghine» (Los pintores). Mokhtar Djaafer (1953), cuyas obras están en la encrucijada del grabado y la pintura, Arezki Larbi (1955) en sus 'pirogramas', o en sus posteriores lienzos de colores intensos, Mohand (I960) liberando por ráfagas u ondas lentas las innumerables especies del signo, aún serían representante de esta tendencia. Abdelouahab Mokrani (1956), en sus rostros y cuerpos ahogados en la materia, y Djilali Kadid (1956), por otro lado, persiguen itinerarios más expresionistas. Bâaziz Hammache (1956) realizó un mural durante los Juegos Africanos de 1978, donde lideró el grupo junto a M'hamed Issiakhem.

Philippe Amrouche (1966) rememora su forma de ser, bajo las luces de la arena o las arcillas rojas, los puntos y triángulos, mezclando alquitranes, polvos, tintas y barnices, incorporando los materiales más diversos, practicando collages. Hoy en día recurriendo a eventos y espectáculos, muchos de estos artistas trabajan no sólo en el lienzo, sino que frecuentemente se prefiere la ausencia de cualquier marco, también en madera, cartón y otros soportes más inusuales: ventanas así saturadas o cortinas de Raouf Brahmia (1965) sobre las cuales restos de cosas e imágenes, o pizarras, maletas, elementos de electrodomésticos, bandejas y secciones de vigas que transfiguran a Kamel Yahiaoui (I966).

$\mathrm{El}$ pintor y escultor Bachir Belounis (1950-2003) es famoso por sus pinturas, esculturas y esculturas monumentales abstractas. Otros nombres serían Mohamed Demagh (1930), Mohand Amara (1952), Smail Zizi (1946). Rachid Khimoune (1953) es uno de los principales artistas de esta nueva generación nacida en Francia. Moldeando adoquines, pavimentos 
y rejas, separa las huellas de las ciudades que, recompuestas, se convierten en hombres, mujeres, niños del mundo, Guerreros que se separan de tiempos remotos, etc ${ }^{3}$.

\section{Pintura narrativa e hiperrealista}

Varios pintores de la escuela de Argelia abandonaron el estilo figurativo para adentrarse en una pintura más narrativa e hiperrealista. En este sentido, Hocine Ziani (I953) es uno de los más representativos de este movimiento. El primer plano de sus composiciones se trata con el rigor del clasicismo, mientras que el segundo y el fondo se desvanecen en claves más libres. Su contribución a la ilustración de la historia nacional agregará una gran popularidad a su pintura. Se ha convertido en uno de los más reproducidos en Argelia y el resto del Magreb, incluyendo sus grandes lienzos con temas históricos.

Otros artistas de su generación son Moussa Bourdine (I946) y Noureddine Zekara (1963), quienes sintetizan el estilo figurativo y académico con composiciones hechas de signos y símbolos.

\section{Pintura tradicionalista}

Otra corriente, llamada tradicionalista, ocupa la escena de las artes plásticas al lado de las demás corrientes citadas anteriormente. Sus representantes son Bencheikh, Sahouli, Sahraoui y Krim. Sus obras están formadas por paisajes locales, escenas de guerras, miniaturas, retratos, junto a la pintura tradicional, realista y academicista de Chérif Mennoubi.

\section{Neosurrealismo y neoplasticismo}

En la actualidad además coexisten tendencias que conviven, desde el nuevo surrealismo, con influencias de Baya en la pintora Djahida Houadef, hasta el surrealismo onírico y visionario de Brahim Achir, a las nuevas experiencias de Mourad Messoubeur o el neoplasticismo de Myriam Aitelhara o Nadia Benbouta ${ }^{4}$.

3 Cf. Fanny Gillet-Ouhenia, "Práctica artística y tratamiento de la imagen en la Argelia poscolonial (1962-1965)”, Quaderns de la Mediterrània, 2011, núm. 15, pp. 209-215.

4 Véase Émilie Goudal, "El concepto de hibridación en el arte contemporáneo argelino", Qua- 
Faiza Maghni (1964) es una pintora surrealista abstracta, que nació en Orán pero reside en París, apasionada de la miniatura persa, se declara autodidacta. Se ha hecho famosa por su colección de retratos con una visión personal sobre la mujer ${ }^{5}$.

El estilo pop art, con influencias del cómic, el realismo fotográfico, etc., hacen de Argelia un territorio diverso en artes y estilos pictóricos, una simbiosis de influencias y producciones propias, síntoma de una sociedad abierta plenamente a cambios artisticos internacionales y con un legado pictórico milenario 6 .

derns de la Mediterrània, 2011, núm. 15, pp. 215-220.

5 Cf. Julia Barroso Villar, Mujeres árabes en las artes visuales: los países mediterráneos, Zaragoza, Prensas de la Universidad de Zaragoza, 2016.

6 Agradecemos al profesor Tomás Andreu González la inestimable ayuda que nos ha brindado para la realización del presente trabajo. 
62 Dianelys Blanco González

ApÉndice ICONOGRÁfico

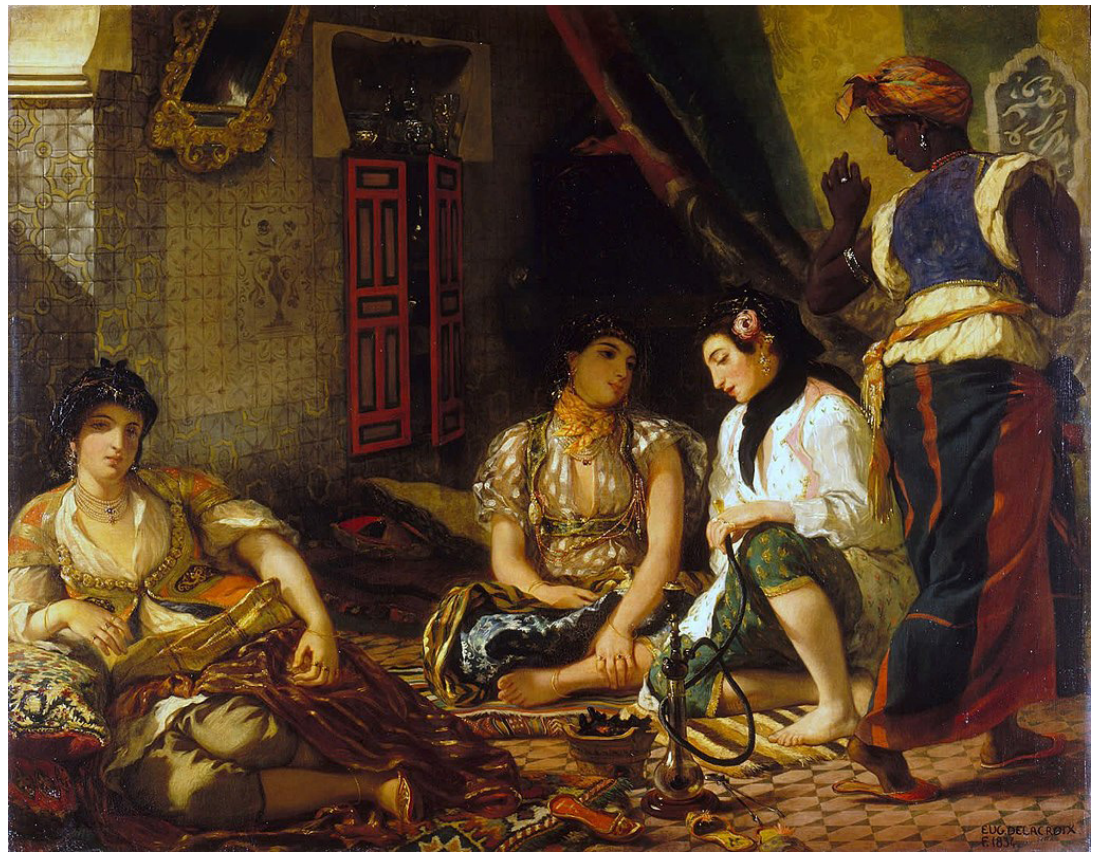

Mujeres de Argel de Eugène Delacroix (1834) 


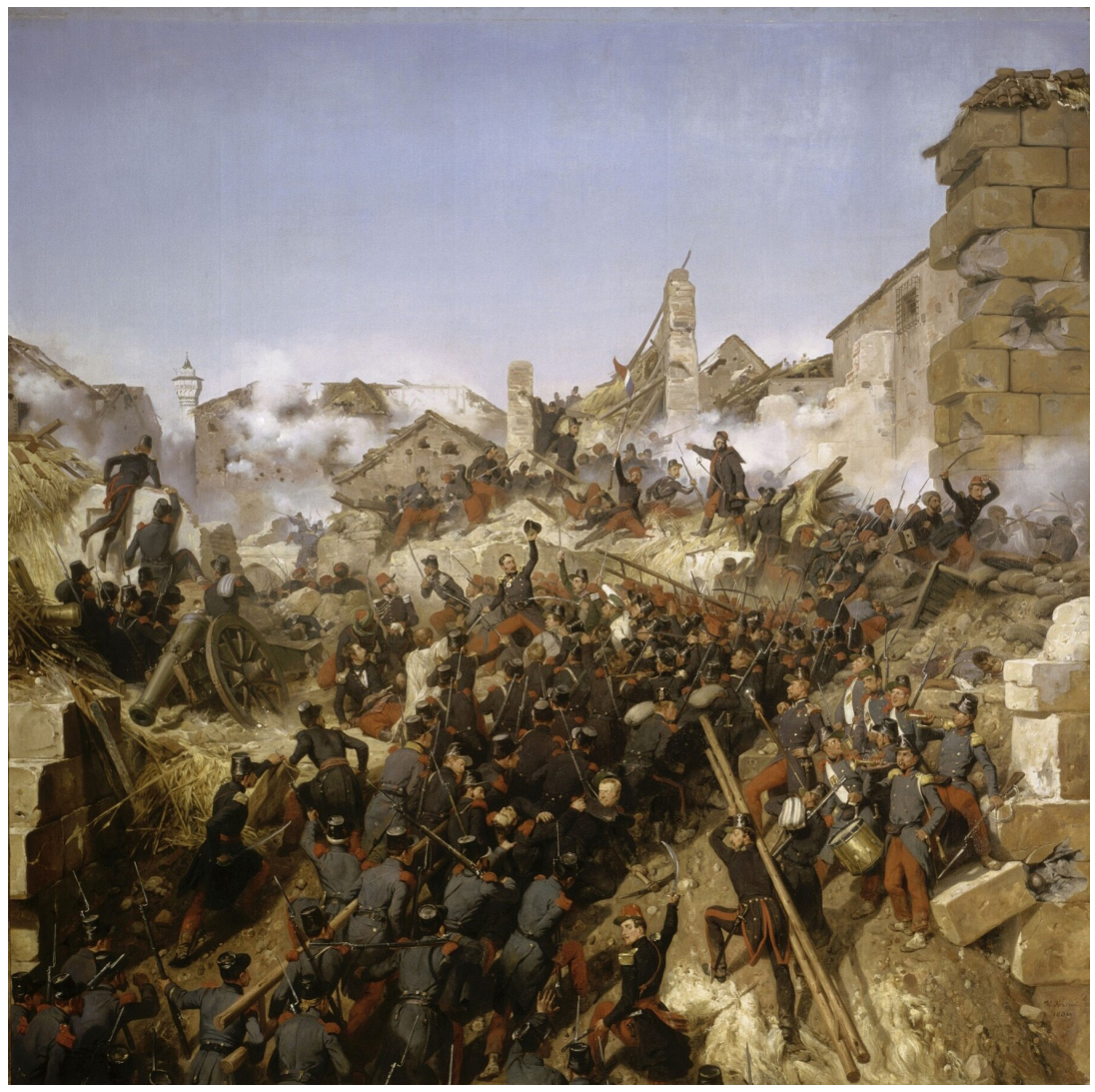

La toma de Constantina de Horace Vernet (1837) 
64 Dianelys Blanco González

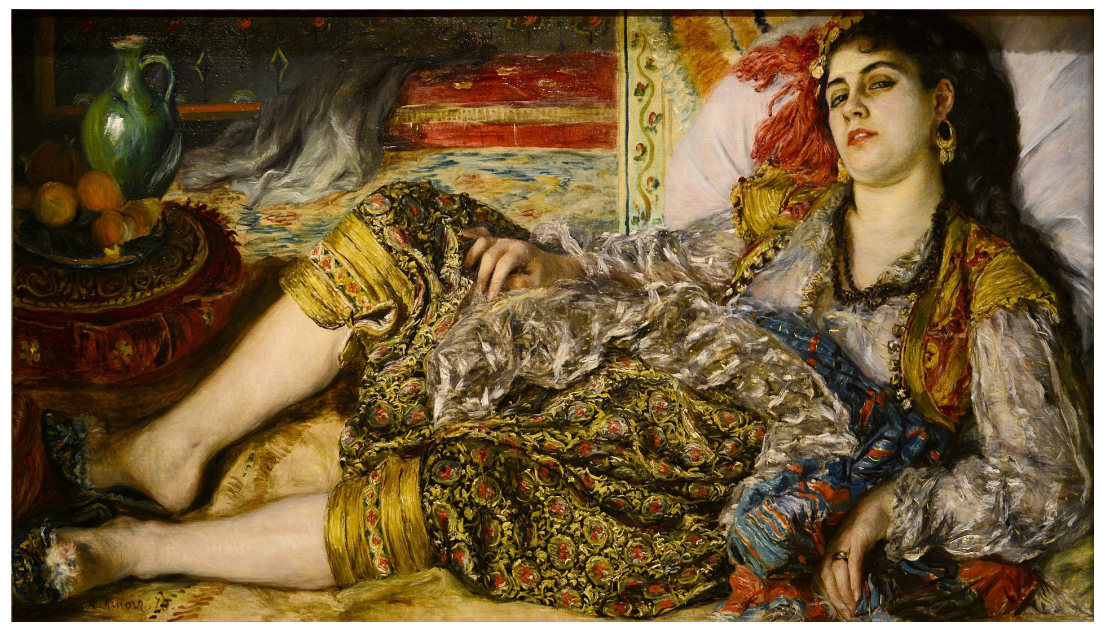

Odalisca. La Argelina de Renoir (1870) 


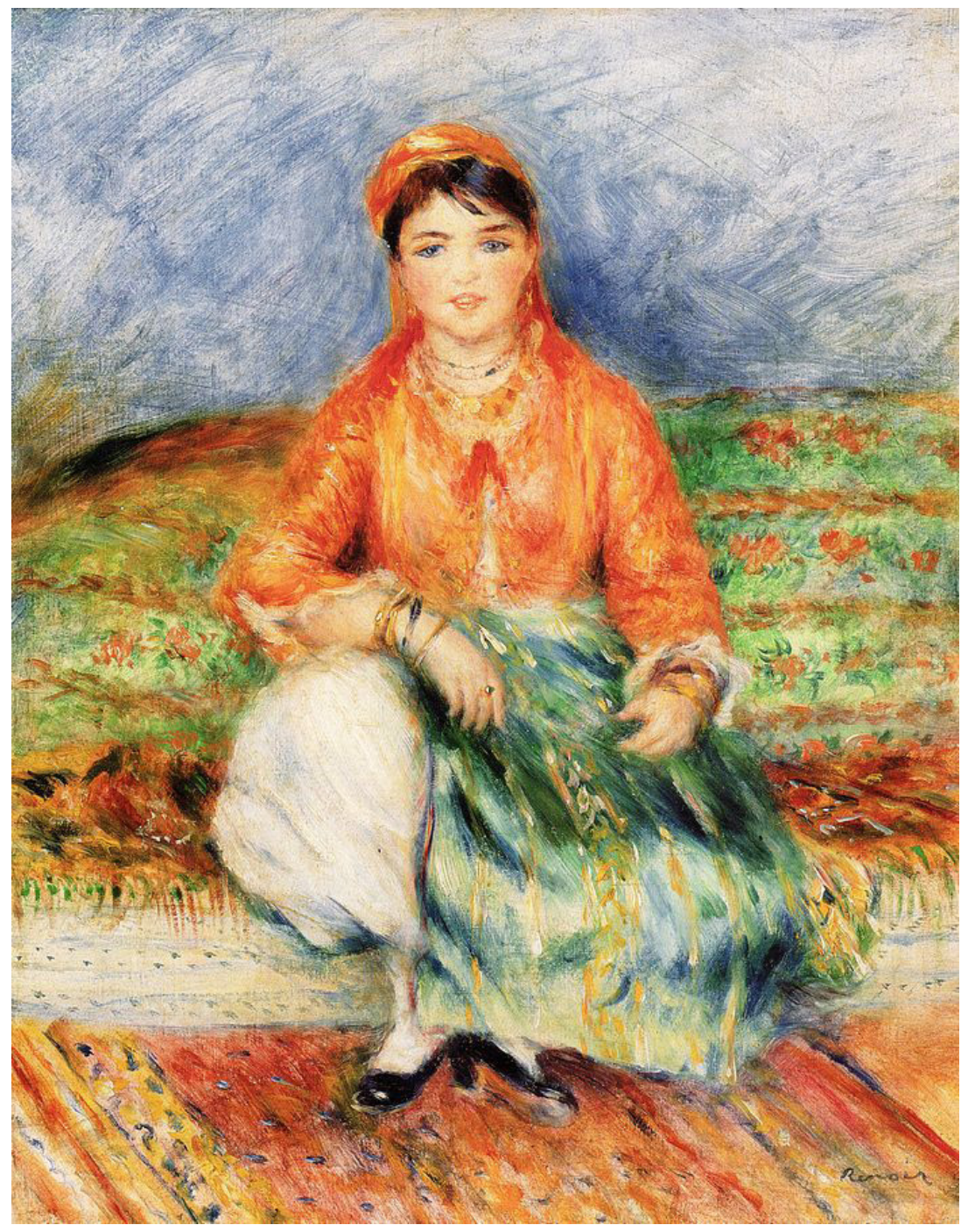

Chica de Argelia de Renoir (1881) 
66 Dianelys Blanco GonzÁlez

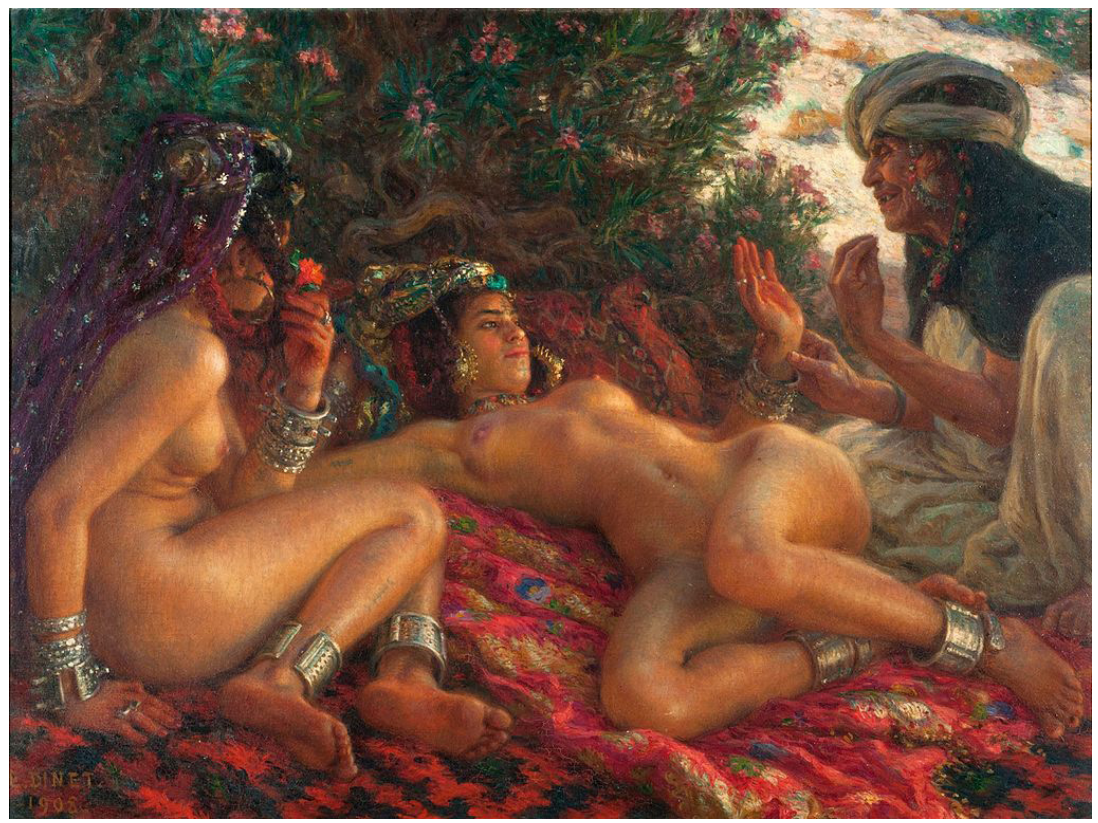

La mensajera de Satanás de Étienne Dinet (1908) 
Aproximación a la pintura argelina contemporánea 67

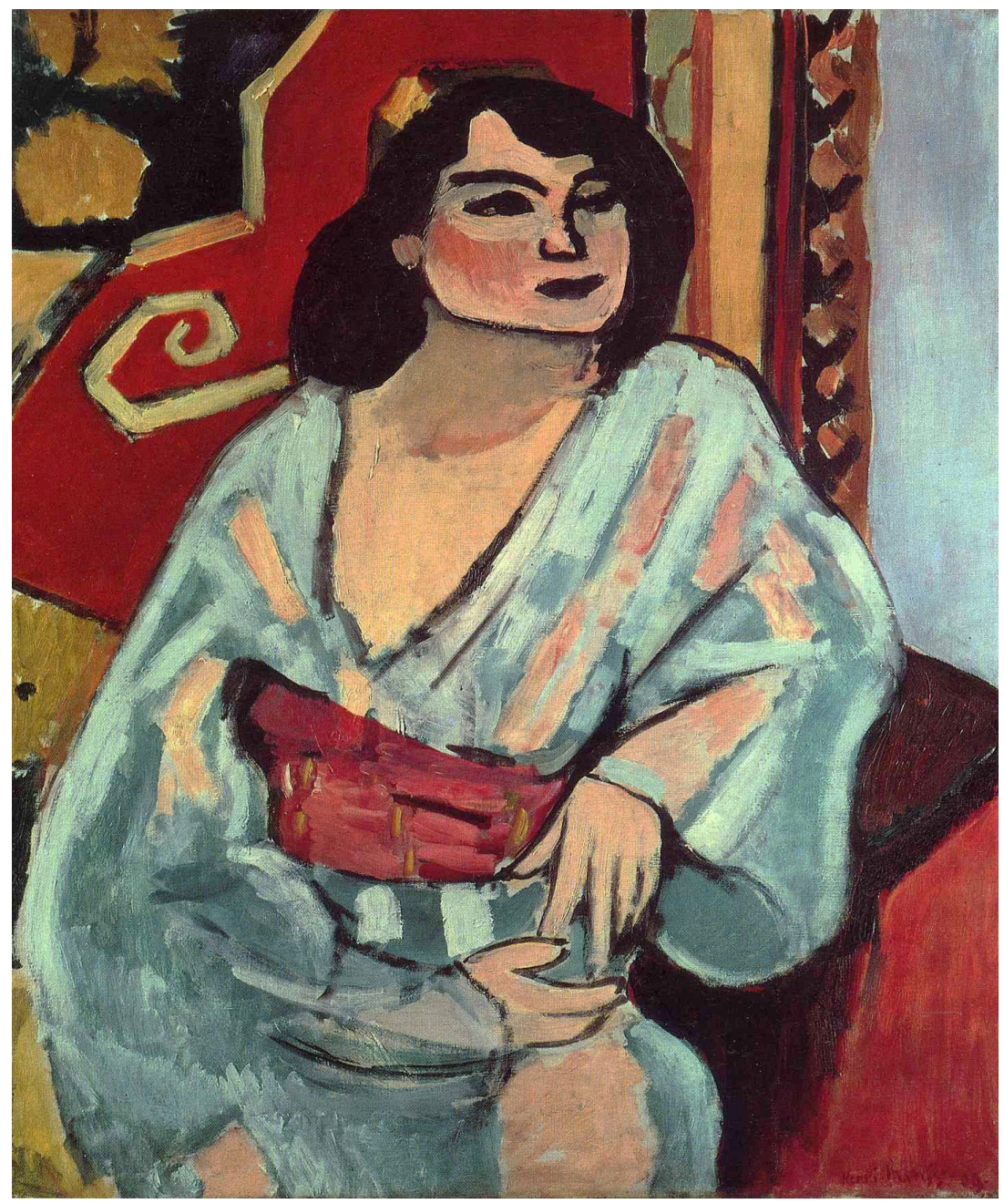

L'Algérienne de Matisse (1909) 
68 Dianelys Blanco González

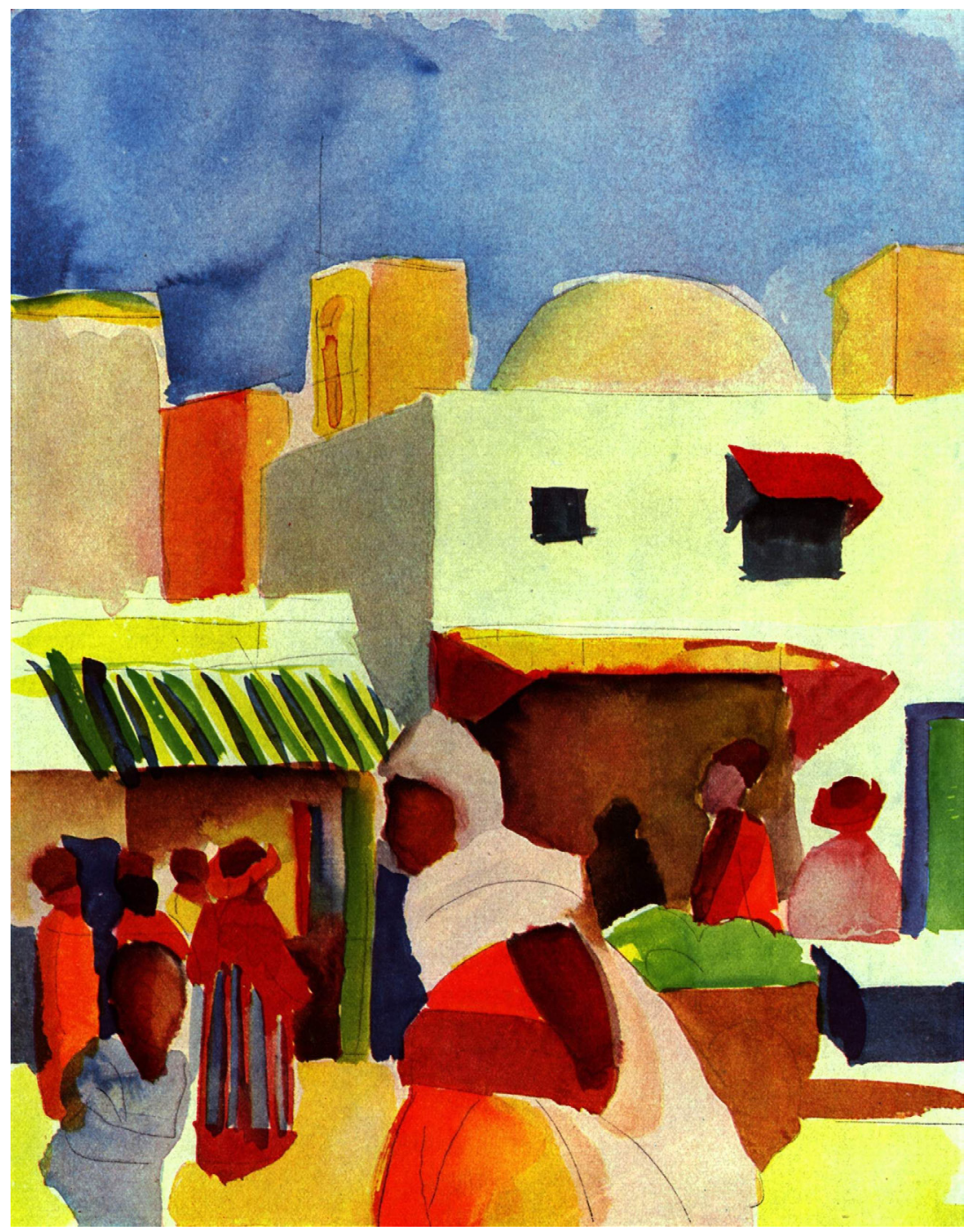

Mercado en Argel de August Macke (1914) 


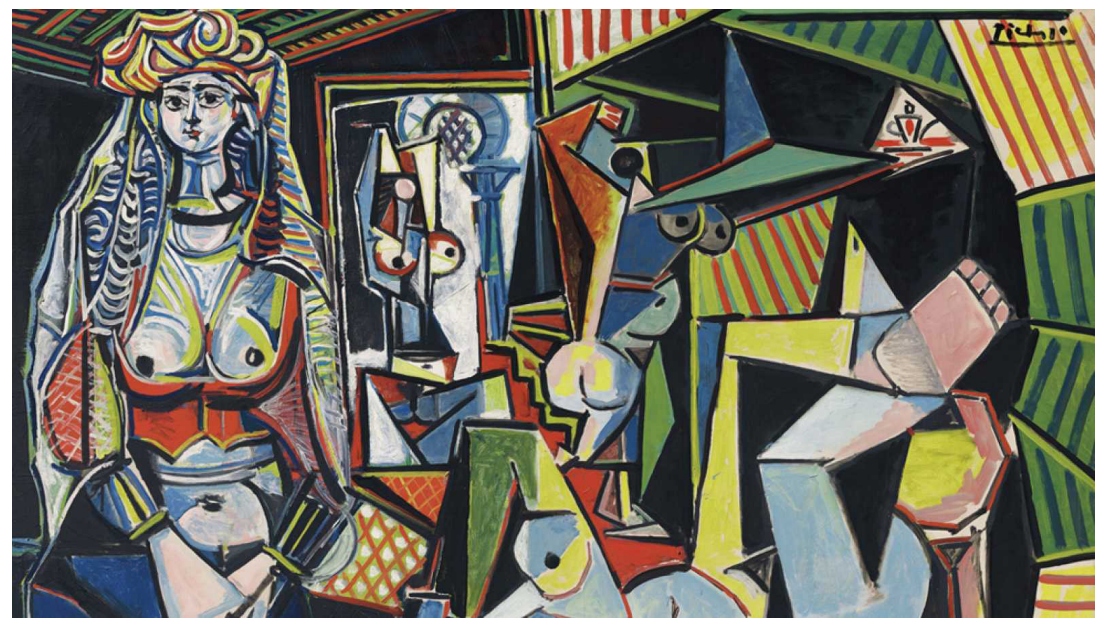

Mujeres de Argel de Picasso (1955) 
70 Dianelys Blanco González

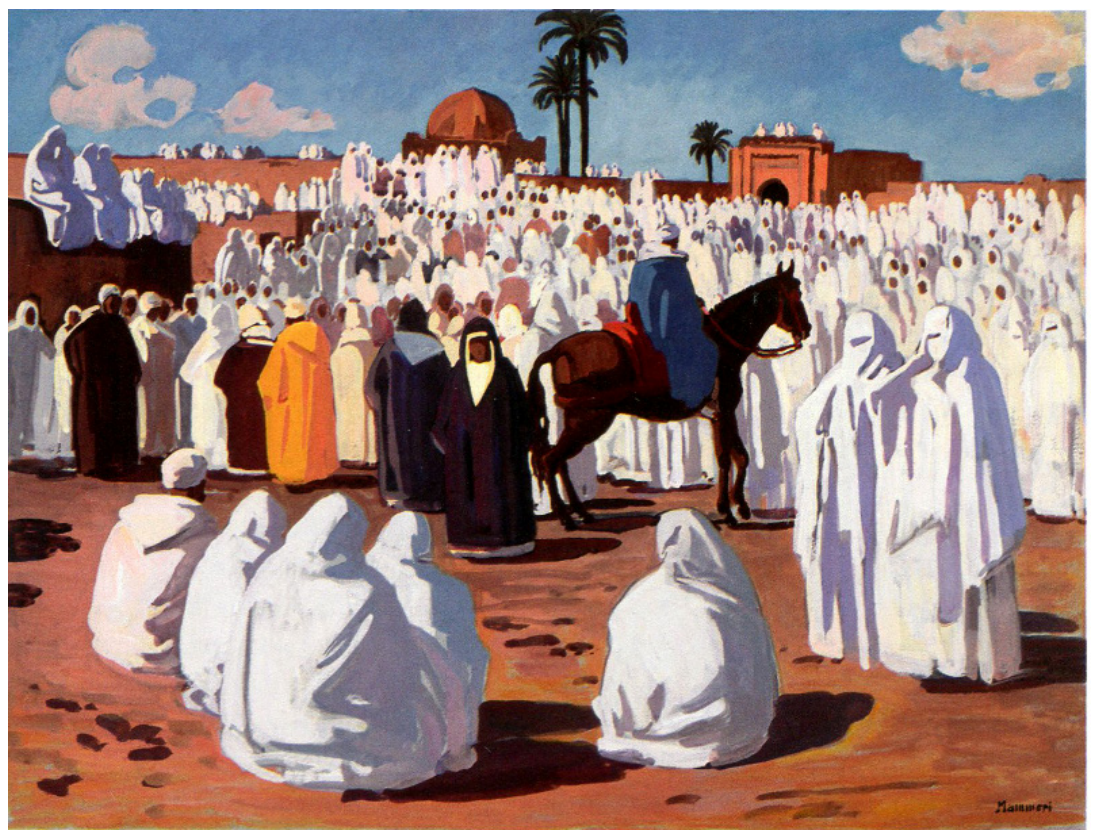

Fete marocainne a Marrakech de Azouaou Mammeri (1930) 


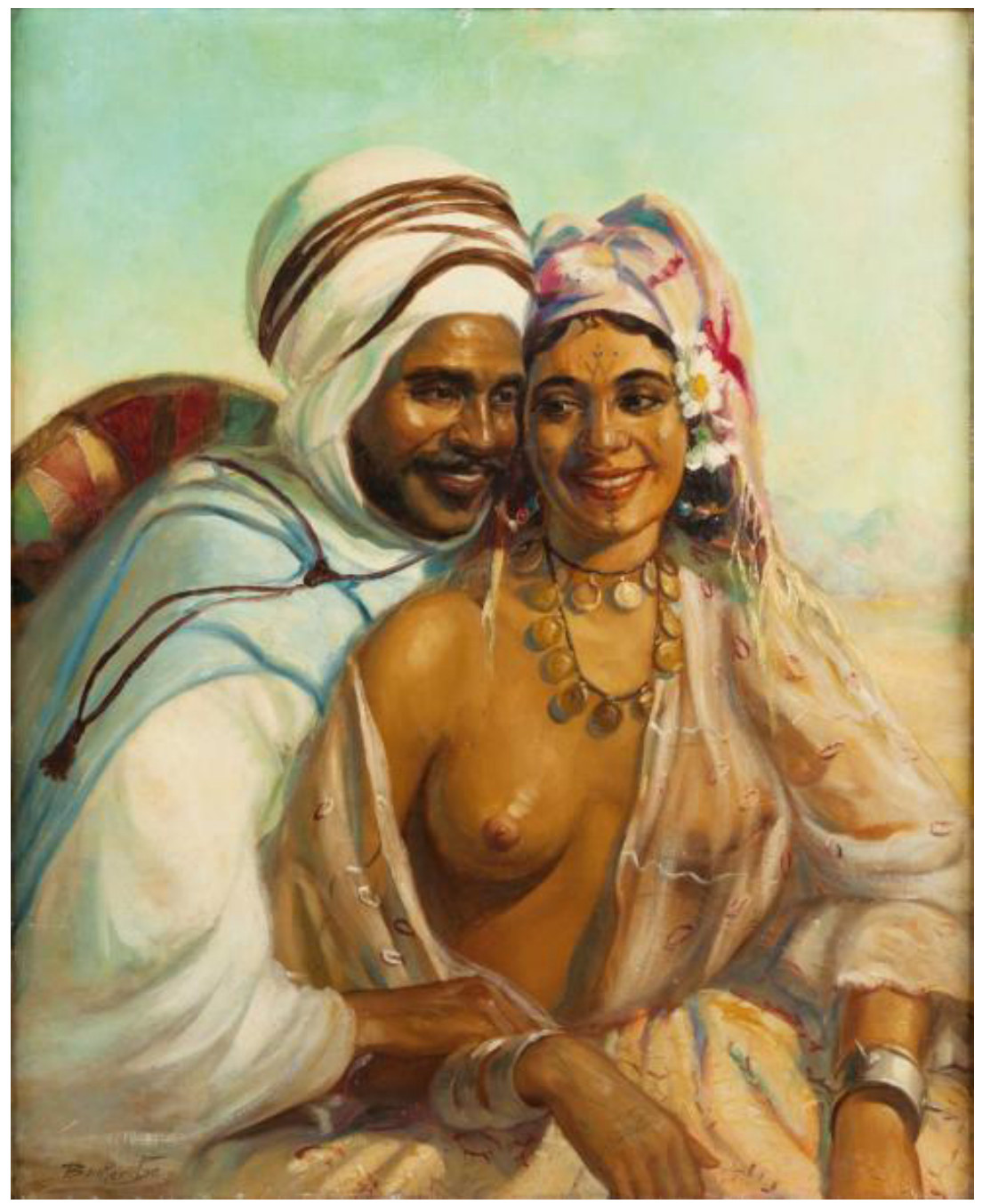

Conversation amoureuse de Miloud Boukerche 


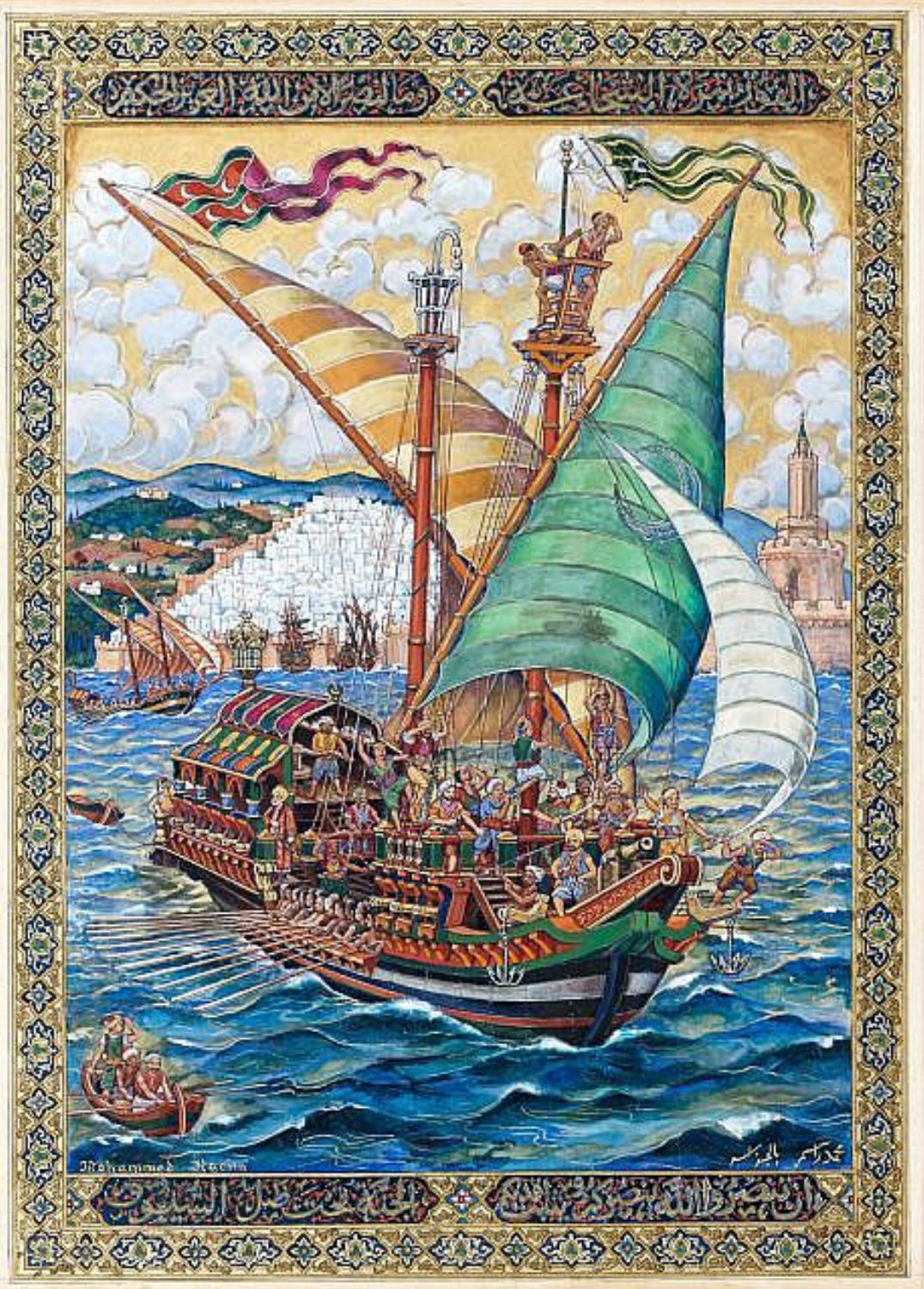

Baie d'Alger de Mohamed Racim 


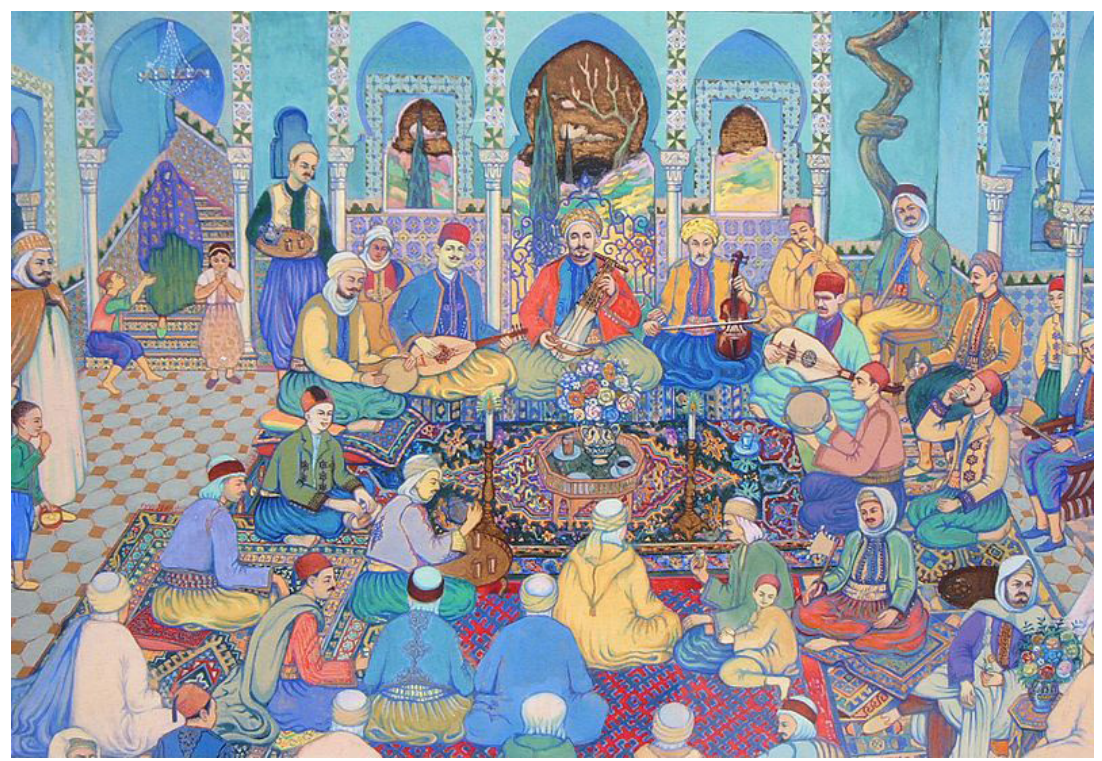

Músicos argelinos en Tremecén de Bachir Yellès 
74 Dianelys Blanco GonzÁlez

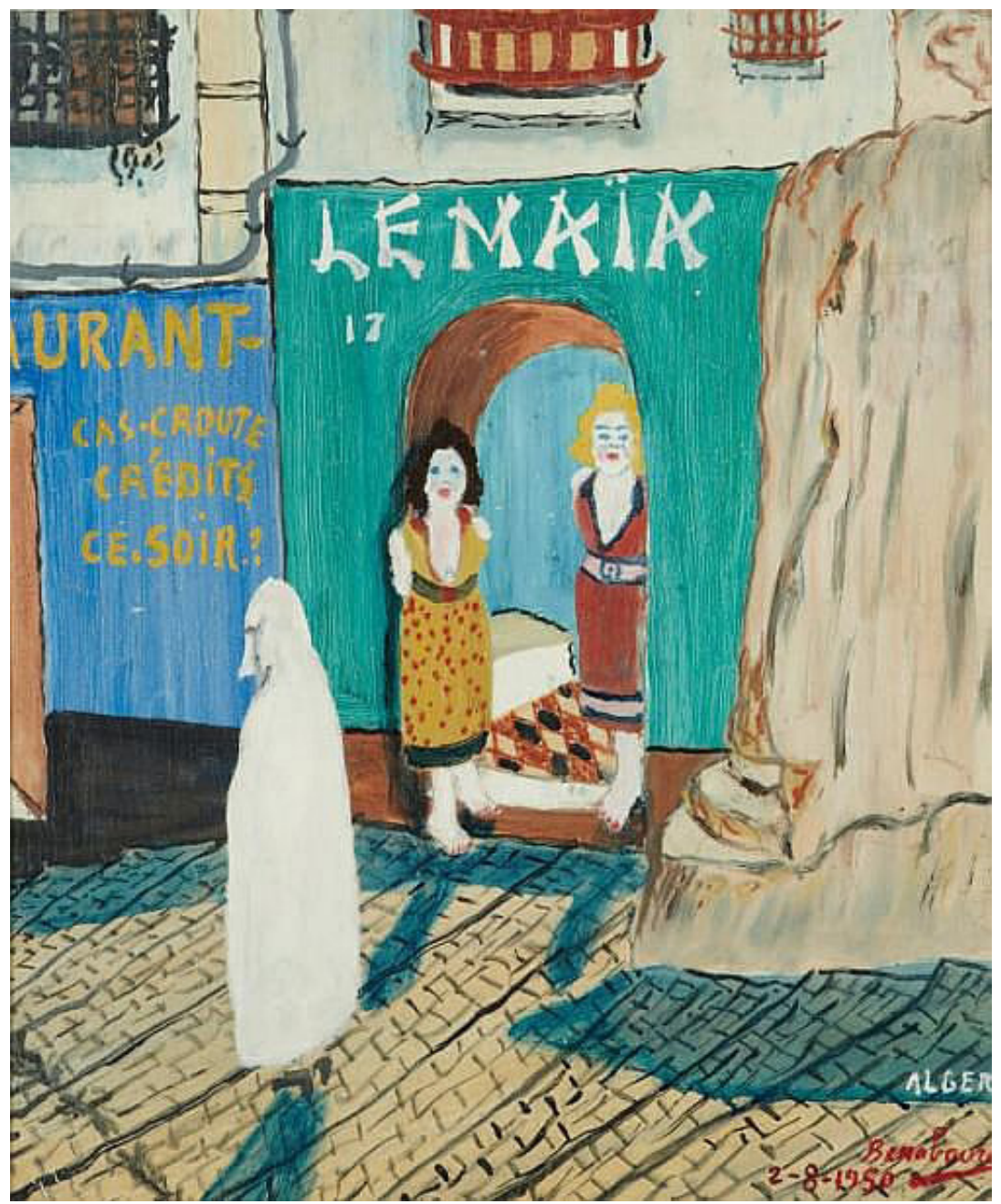

Calle de Argel de Hacène Benaboura (1950) 


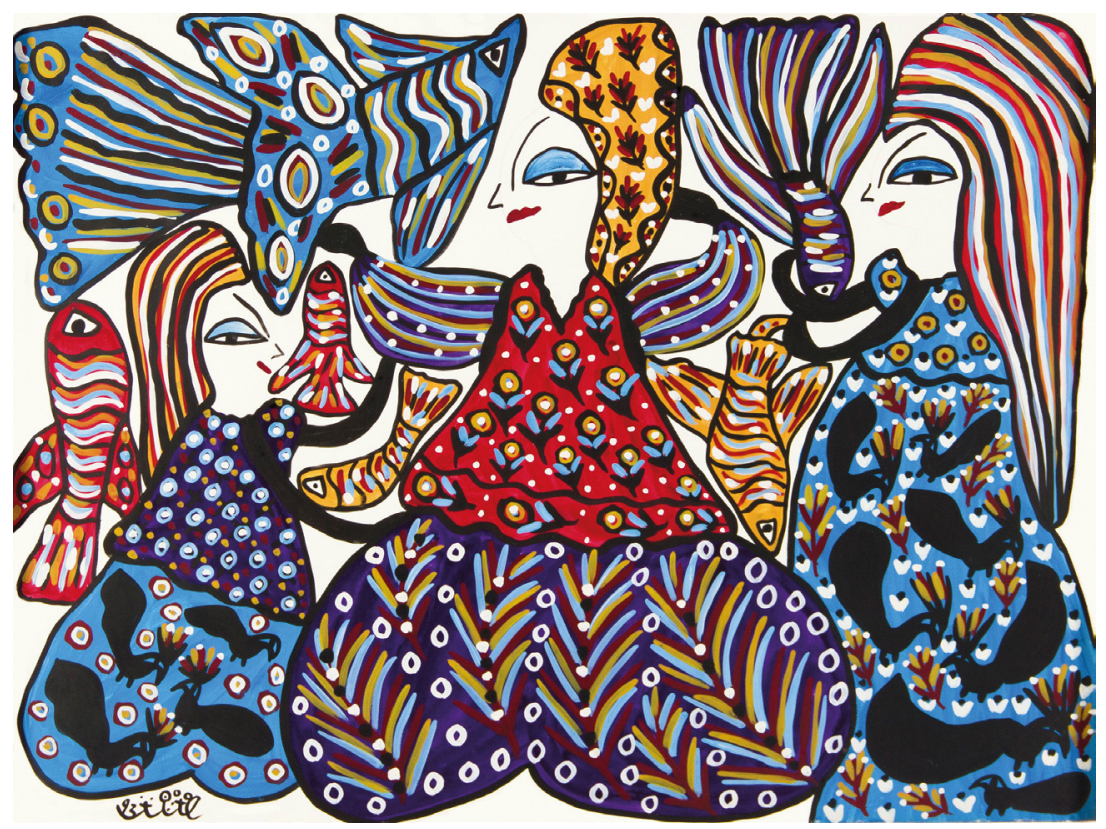

Sin título de Baya Mahieddine (1992) 
76 Dianelys Blanco González

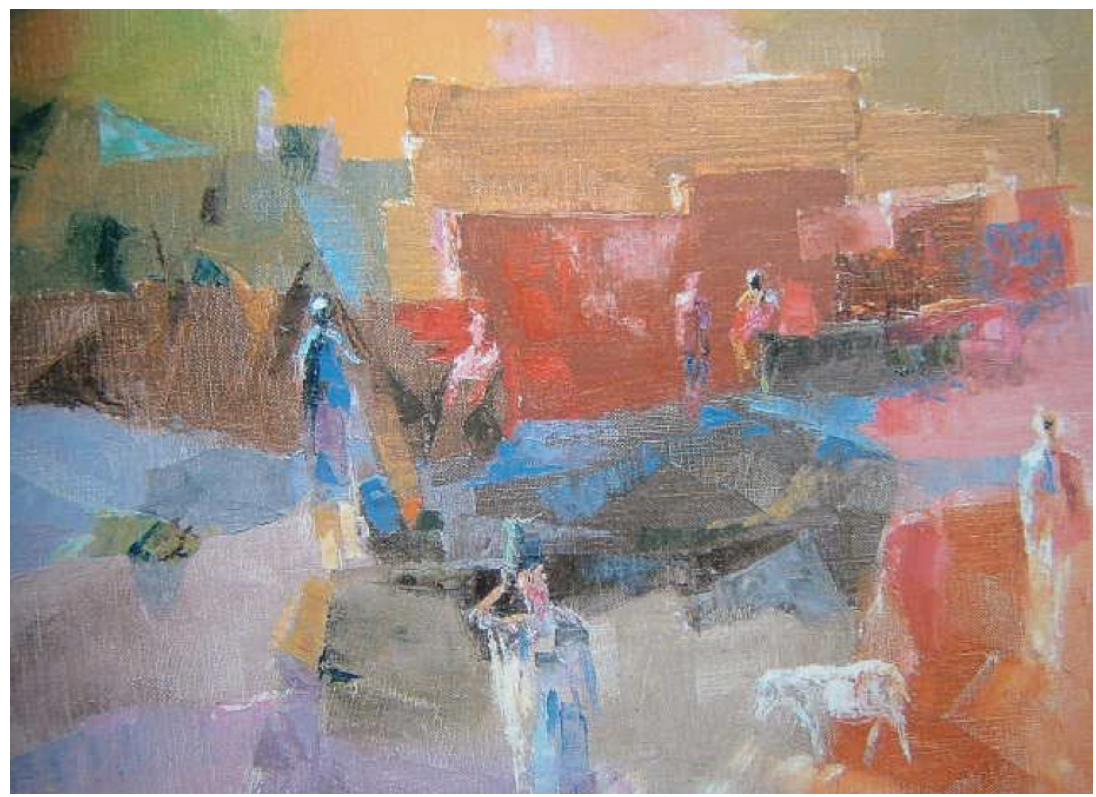

Composición de Mohamed Bouzid 


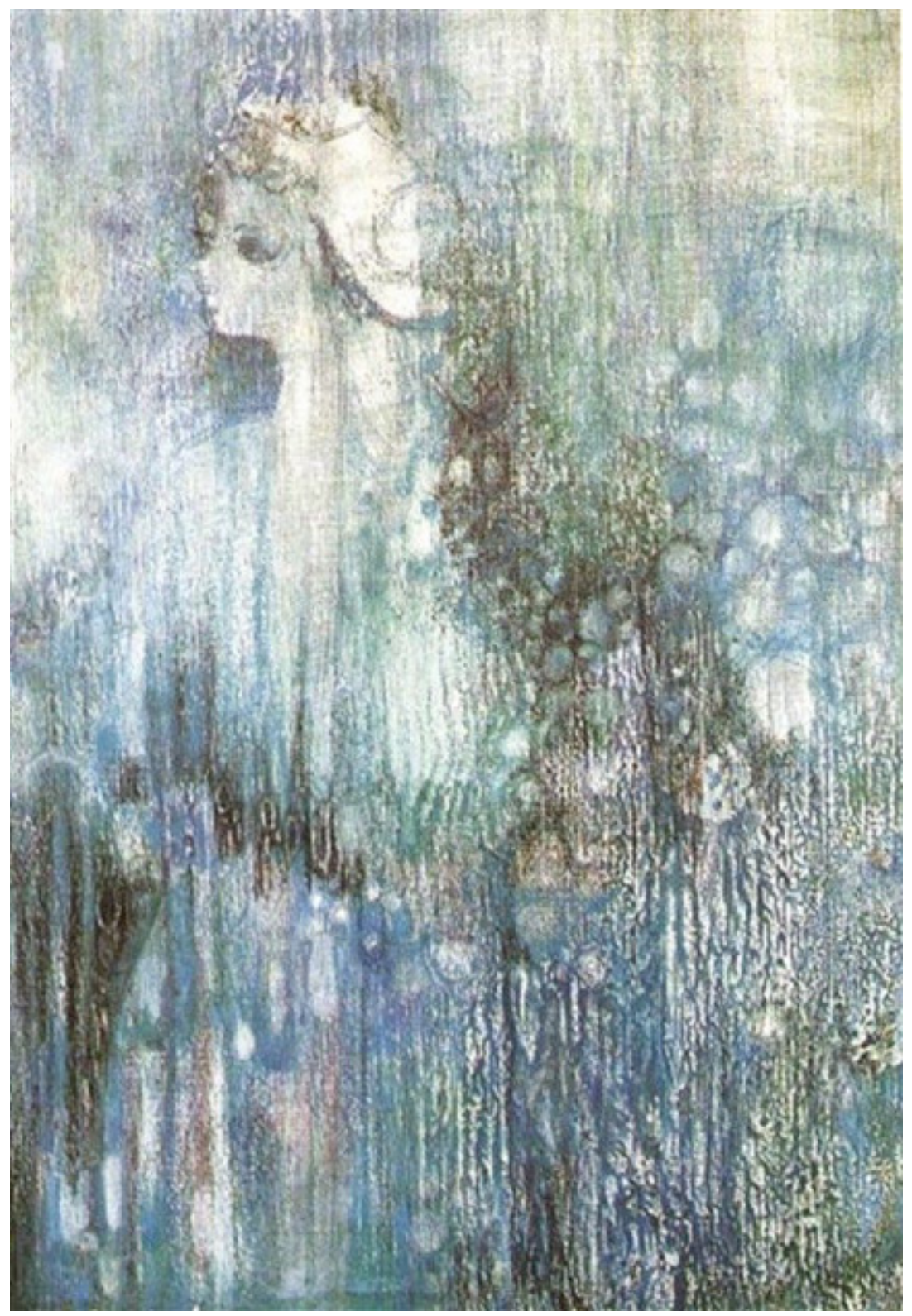

Embrun bleu de Ismail Samsom 
78 Dianelys Blanco González

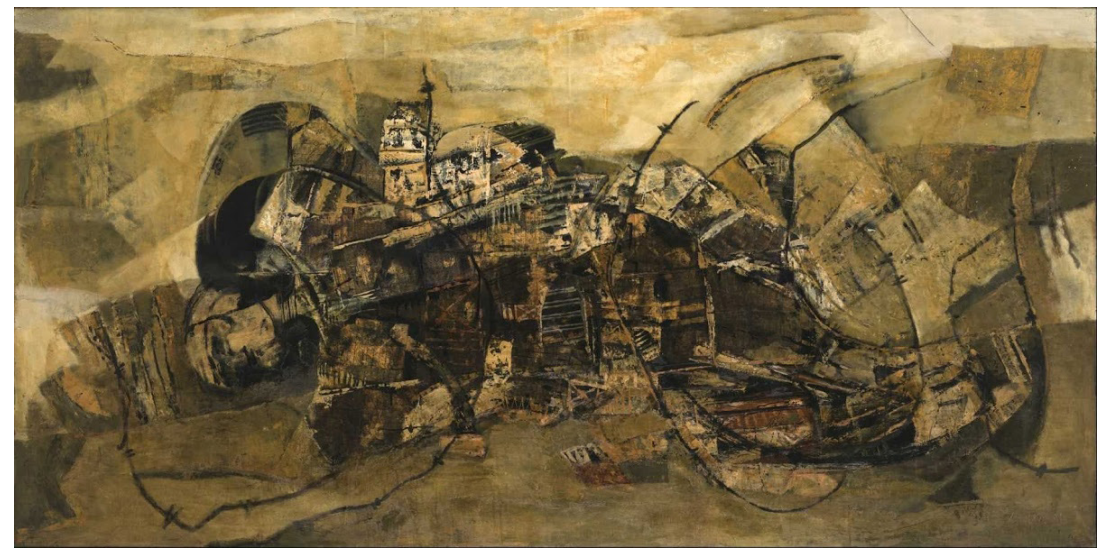

La resurrección de Fénix de M'hamed Issiakhem 


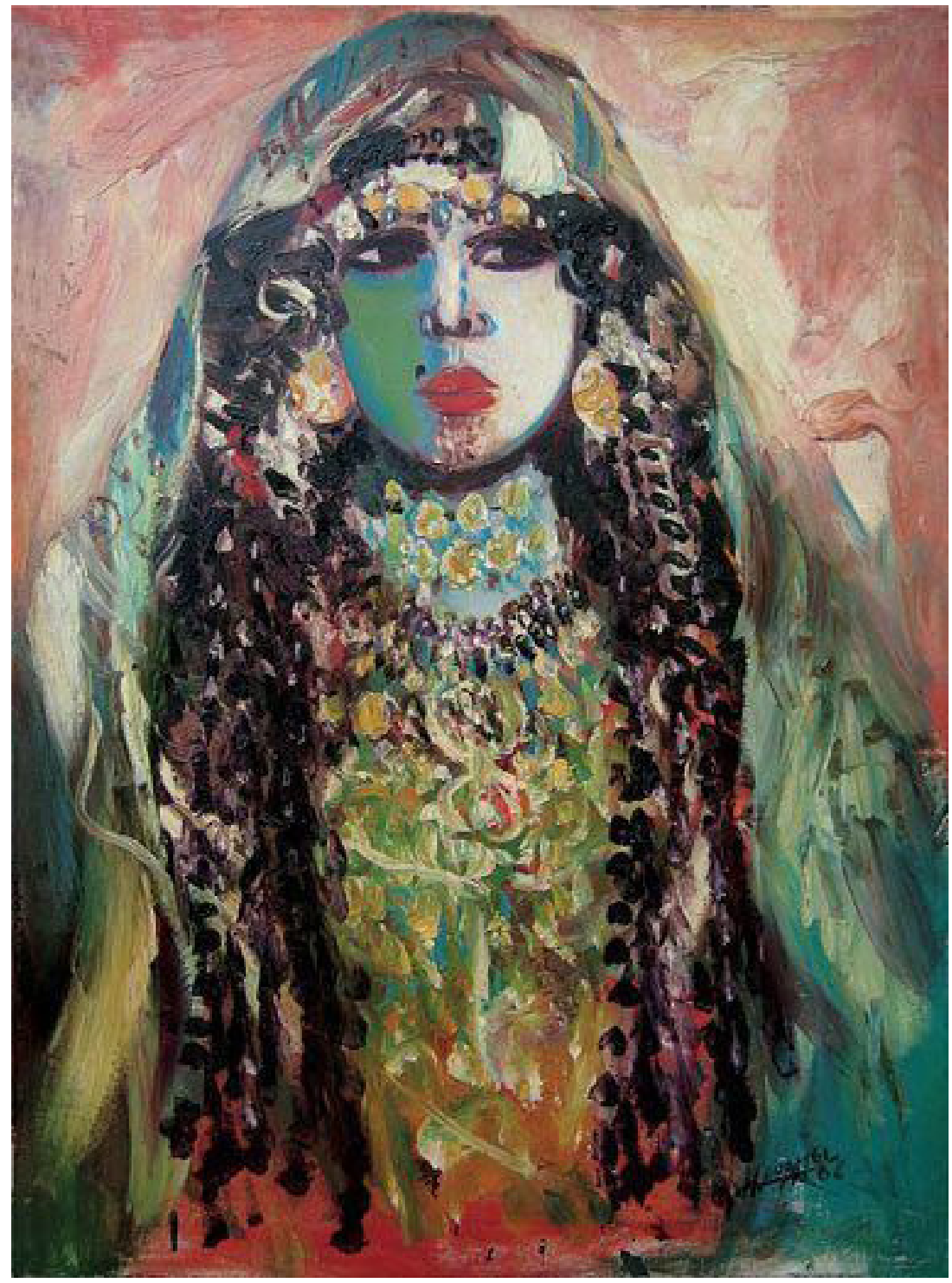

La petite fiancée bédouine de Abdelkhader Houamel (1968) 
80 Dianelys Blanco González

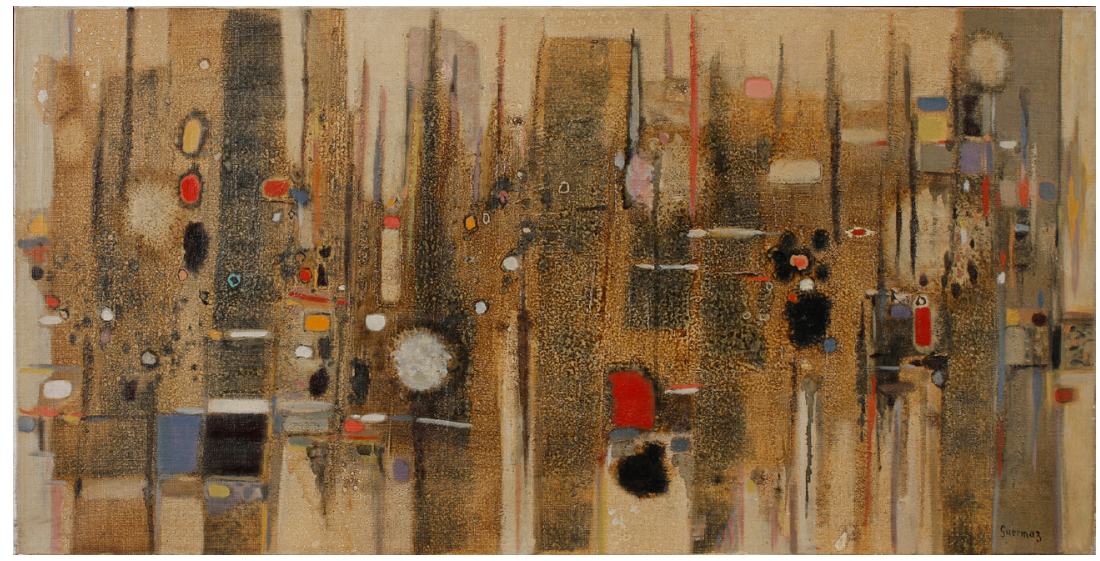

Composición de Abdelkader Guermaz (1965) 


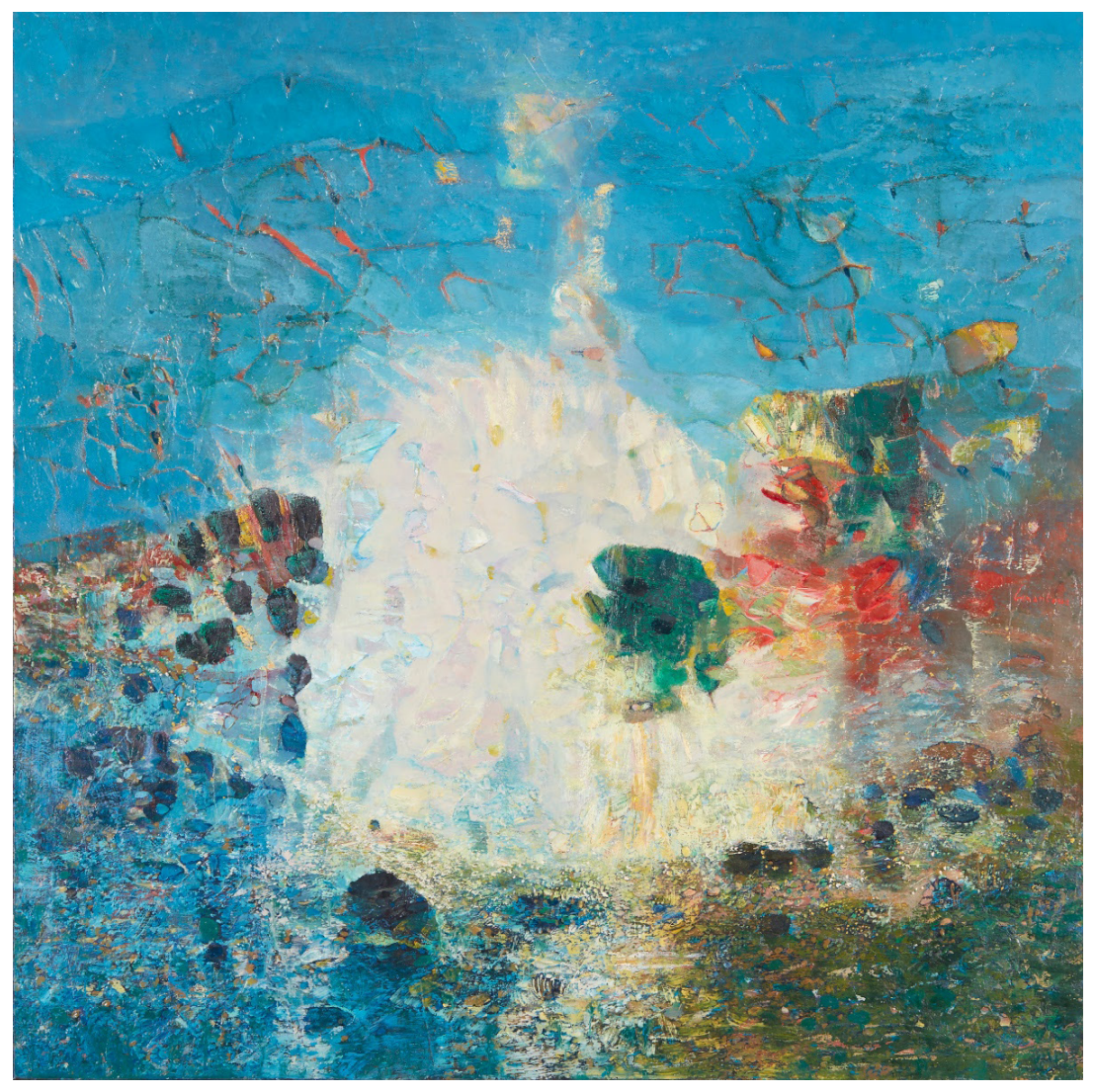

To Monet.Giverny de Abdallah Benanteur (1983) 
82 Dianelys Blanco González

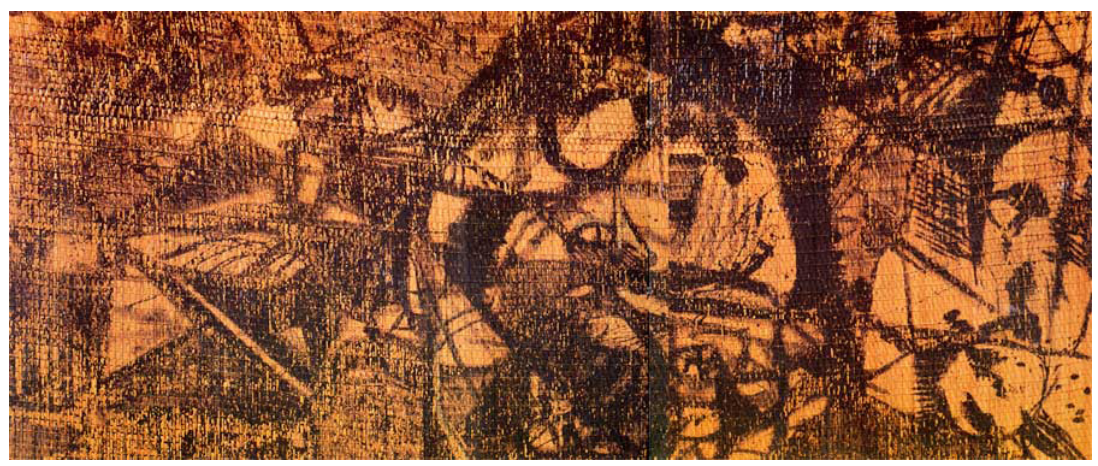

Sans titre de Choukri Mesli (1967) 


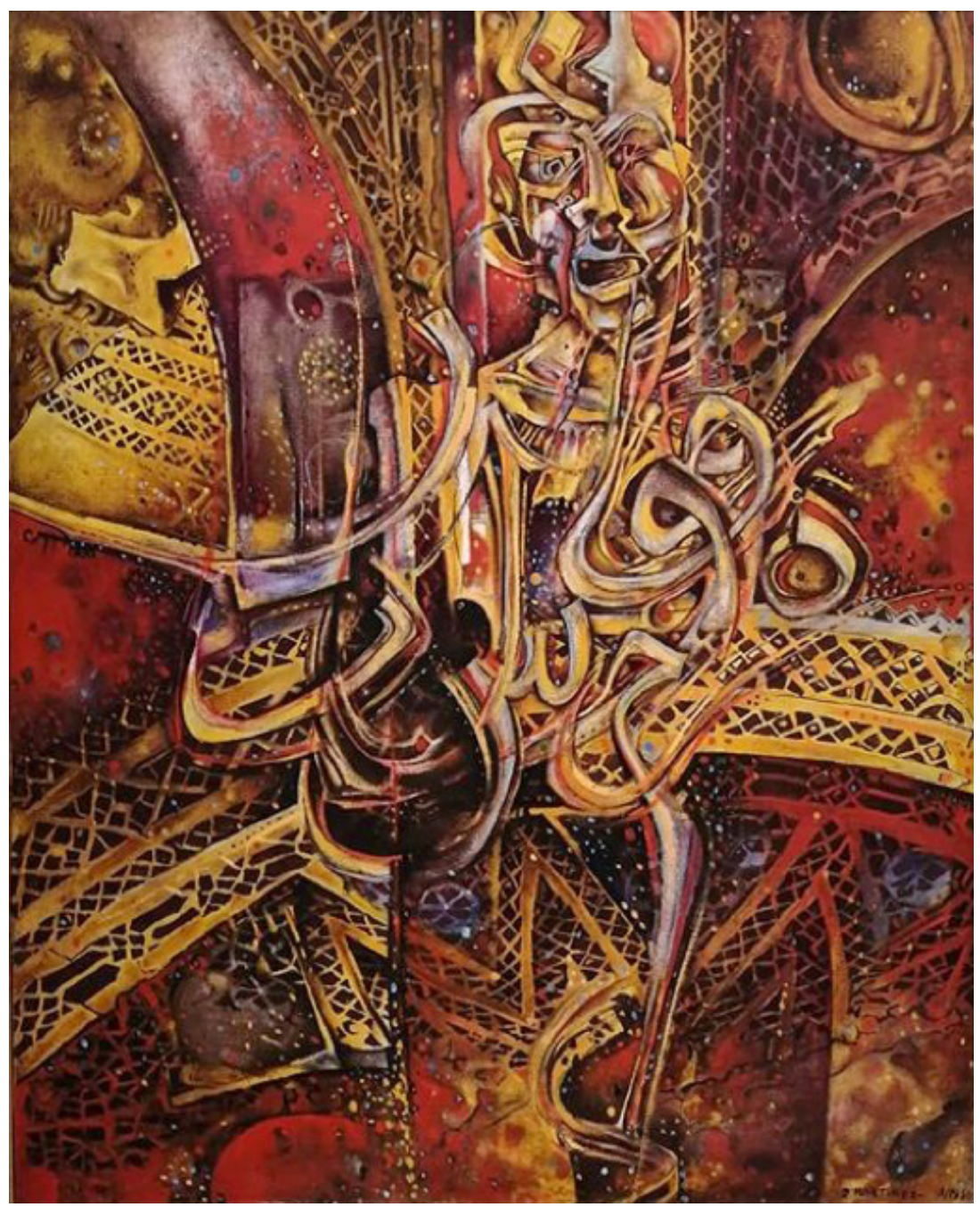

Douloureuse identification 2 de Denis Martínez (1980) 
84 Dianelys Blanco González

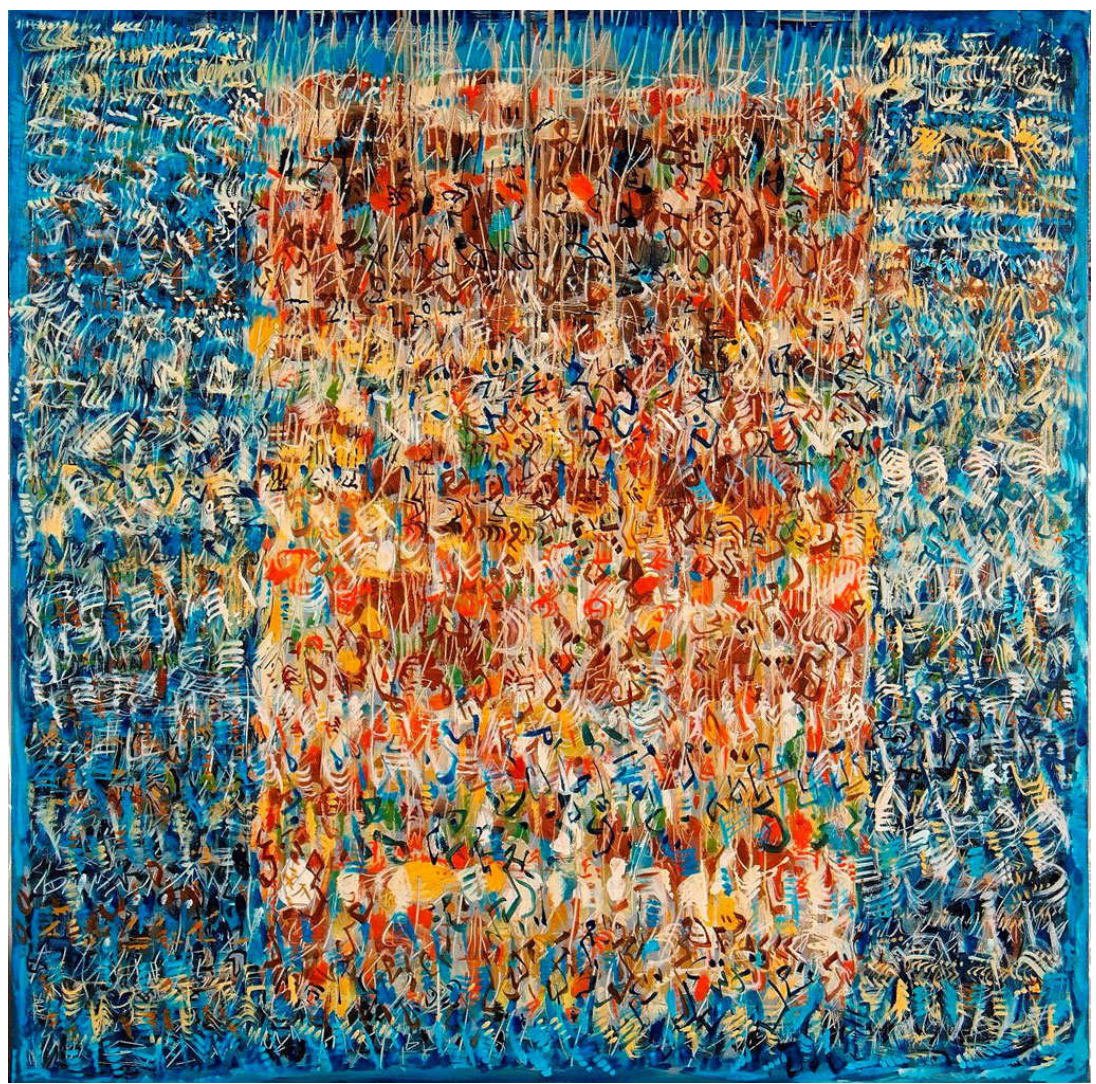

Carré magique de Mahjoub Ben Bella (2004) 


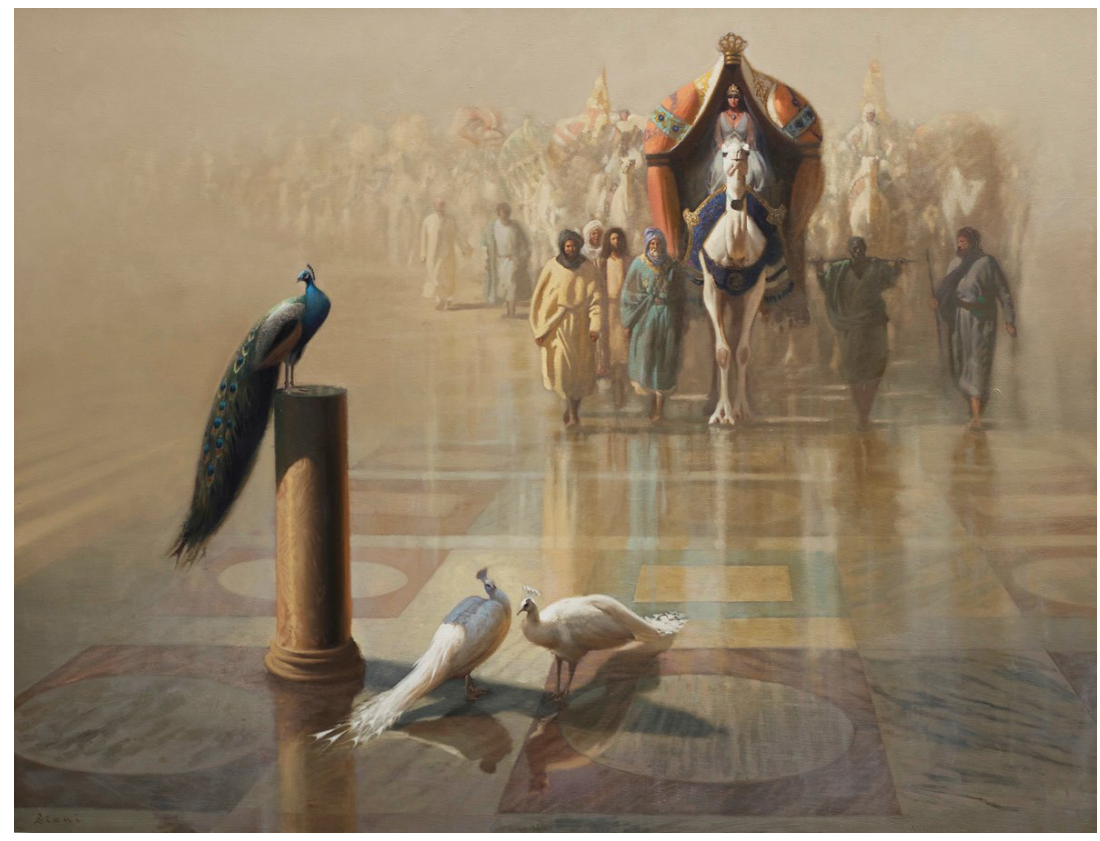

La reina de Saba de Hocine Ziani (2015) 
86 Dianelys Blanco González

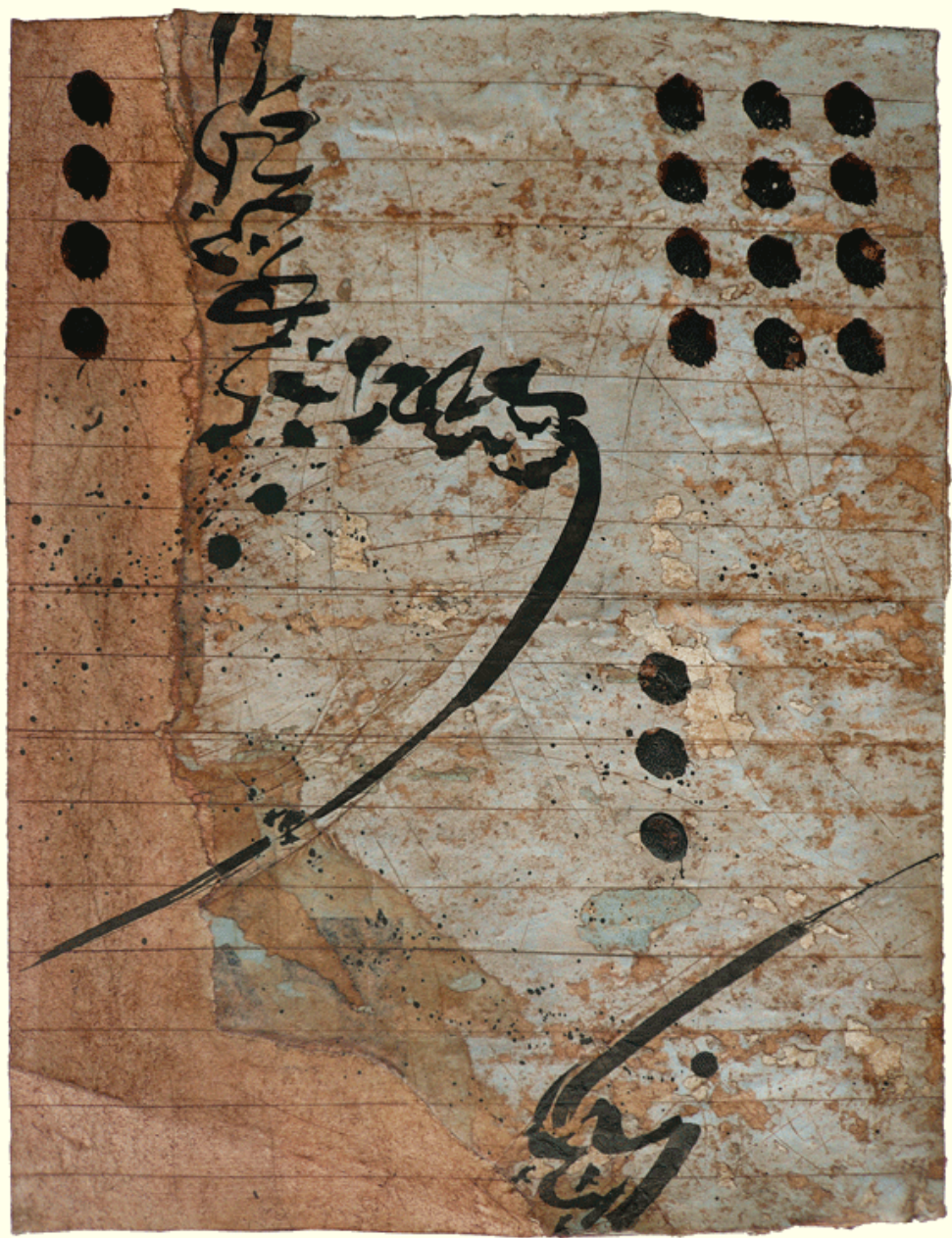

Traite de navigation de Hamid Tibouchi 


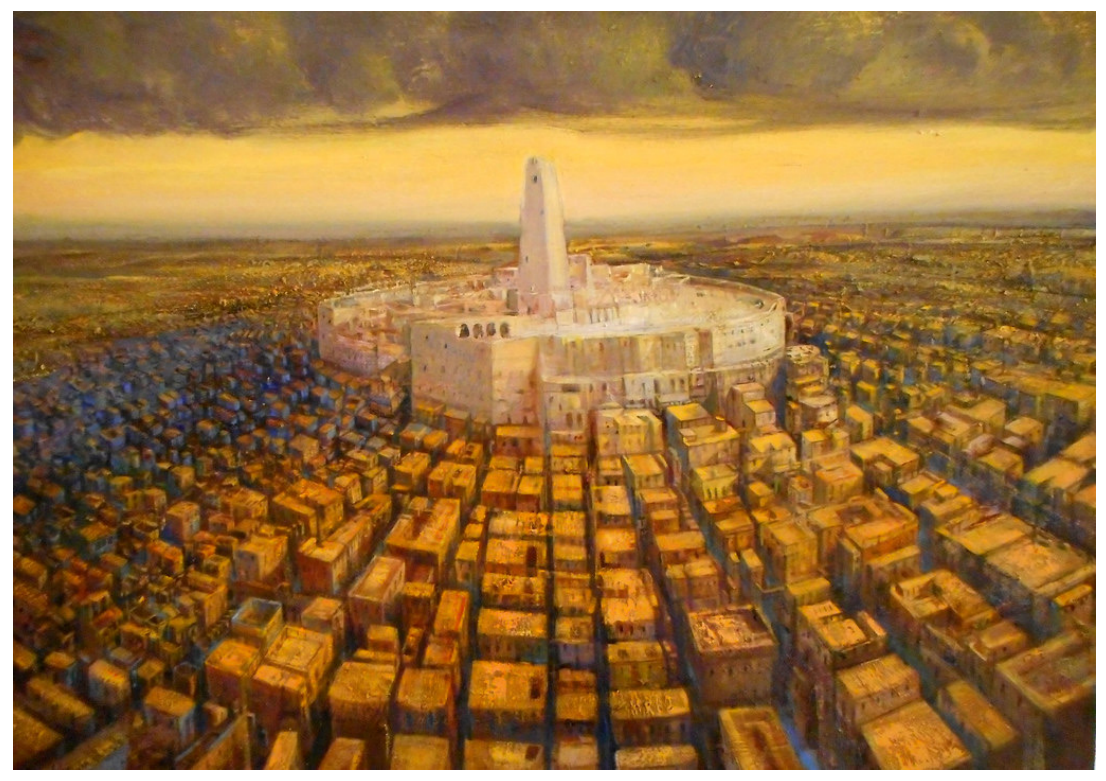

Pueblo del desierto de Brahim Achir (2018) 
88 Dianelys Blanco González

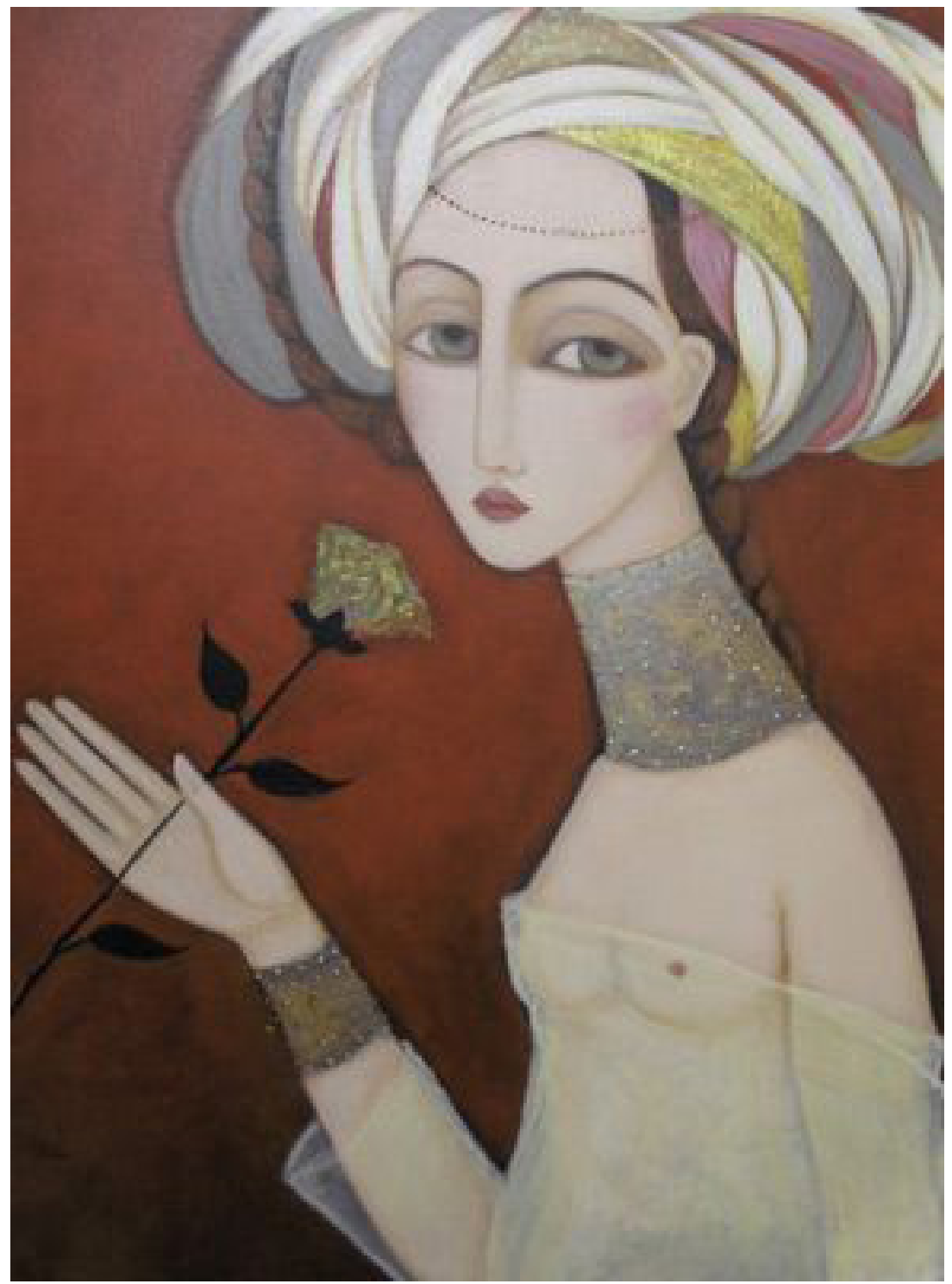

La rose de Faiza Maghni 


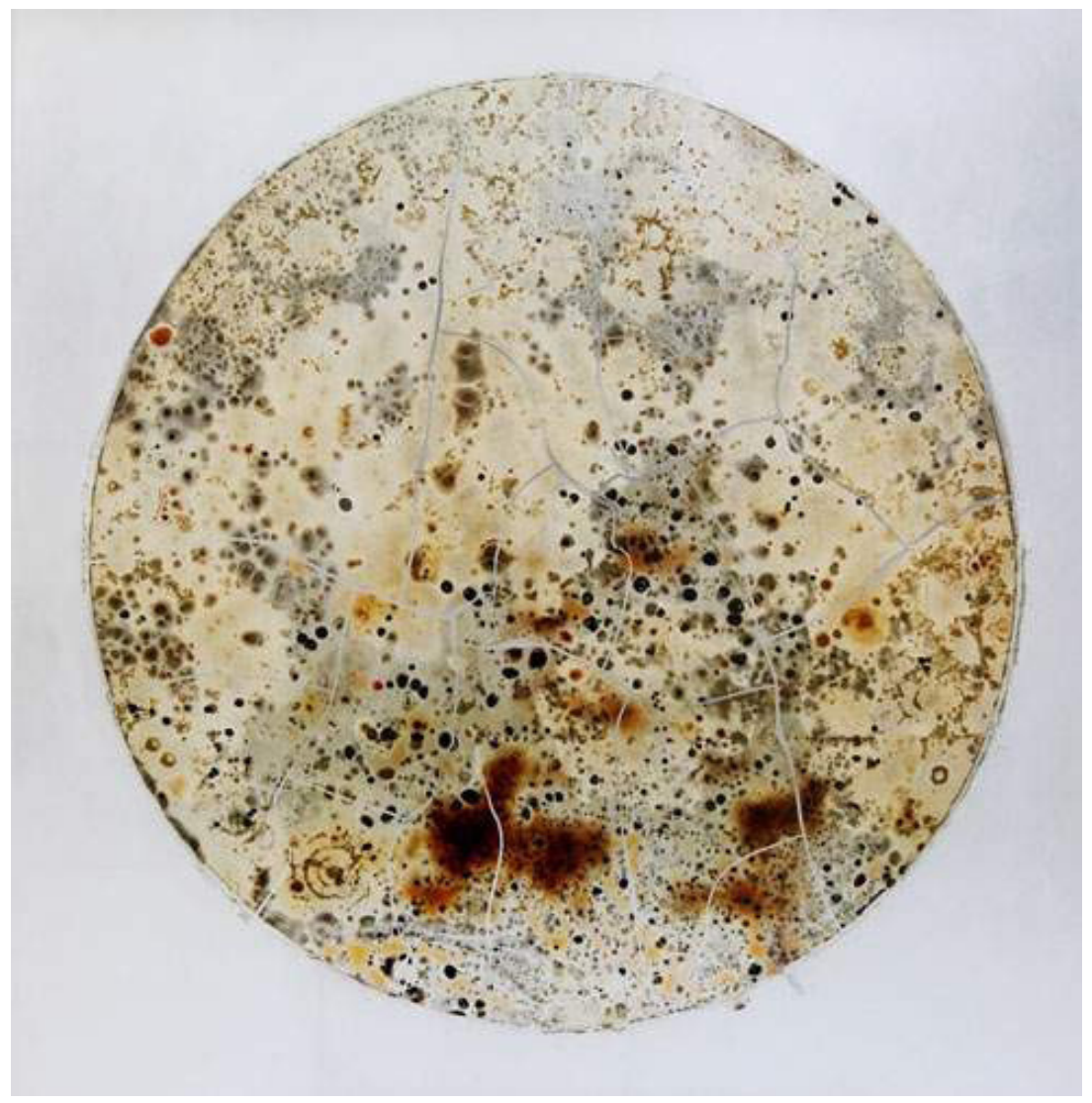

Sphère 2007 de Mourad Messoubeur (2007) 
